\title{
Impact of prebiotics, probiotics, and gut derived metabolites on host immunity
}

\author{
Richard Y. Wu ${ }^{a, b \dagger}$, Michael P. Jeffrey ${ }^{c \dagger}$, Kathene C. Johnson-Henry ${ }^{a}$, \\ Julia M. Green-Johnson ${ }^{c}$, and Philip M. Sherman ${ }^{a, b, d *}$
}

\begin{abstract}
Increasing evidence indicates that gut microorganisms impact multiple aspects of the innate and adaptive mucosal immune system. Current research focuses on the potential of prebiotics (non-digestible fibres that nourish beneficial bacteria) and probiotics (beneficial live bacteria) to promote health, prevent disease, and for use as a treatment strategy for a variety of immune-mediated conditions. The immune modulatory effects of probiotics and prebiotics are strain- or structure-specific and vary with disease state, age, and sex. Prebiotics and live beneficial bacteria, including their metabolic products or soluble mediators, have the ability to affect the composition of the intestinal microbiota. As well, they influence the integrity and functions of intestinal epithelial cells and antigen presenting cells, including dendritic cells and macrophages, by both direct and indirect mechanisms of action.
\end{abstract}

Statement of novelty: This review serves to highlight select advances related to the impact of prebiotics, probiotics, and gut microbe-derived metabolites on host immune function.

\section{Introduction}

The immune system includes a complex array of cells and biomolecules, which interact to provide protection from challenge by pathogenic microorganisms. The immune system is divided into 2 major branches, comprised of innate (or non-specific) and adaptive (specific) immune responses. The innate immune system is tasked with rapidly distinguishing between self and non-self, and facilitates activation of the adaptive immune system during microbial challenges. Adaptive immunity is characterized by highly specific responses as well as immunological memory, allowing the host to respond more rapidly to subsequent challenge from a previously encountered pathogen or antigen. While innate and adaptive immunity differ in many aspects, there is extensive communication and interaction between cell types that participate in both types of responses. Some cell types, such as macrophages, are active participants in both arms of host immune function. Commensal gut bacteria play an integral role in the development and regulation of both innate and adaptive immunity (Lathrop et al. 2011; Kabat et al. 2014).

Over the past decade, a wealth of research contributing to the Human Microbiome Project has catalogued the variety of microorganisms that colonize various body surfaces. These include the skin, the vagina, the

${ }^{a}$ Cell Biology Program, Research Institute, Division of Gastroenterology, Hepatology and Nutrition, Hospital for Sick Children, Toronto, ON; ${ }^{b}$ Department of Laboratory Medicine and Pathobiology, Faculty of Medicine, University of Toronto, Toronto, ON; ' Faculty of Science, University of Ontario Institute of Technology, Oshawa, ON; ${ }^{d}$ Faculty of Dentistry, University of Toronto, Toronto, ON

*Corresponding author: Philip M. Sherman/philip.sherman@sickkids.ca

${ }^{\dagger}$ Co-first authors.

LymphoSign Journal 4:1-24 (2017)

dx.doi.org/10.14785/lymphosign-2016-0012 
lungs, the nasal and oral cavities, as well as various segments of the gastrointestinal tract (Marchesi et al. 2016). Most studies to date have characterized bacterial communities, particularly those that are difficult to culture, using culture-independent approaches such as sequencing of various hyper-variable regions of the $16 \mathrm{~S}$ ribosomal RNA gene and shotgun metagenomic sequencing. However, plenty of data are also available on the presence and diversity of non-bacterial microorganisms present on the human body, including Archaea, fungi (Wheeler et al. 2016), viruses, and phages (Monaco et al. 2016). These studies, collectively, have developed an inventory of the microbial diversities present across the lifespan, both in healthy individuals living in various parts of the world, and in various disease states.

Dysbiosis (defined as any change to the composition of resident commensal communities relative to the community found in healthy individuals) (Petersen and Round 2014), is linked to a variety of chronic inflammatory disease states, including Crohn's disease and ulcerative colitis, obesity, and type 1 and type 2 diabetes (Sonnenburg and Backhed 2016). However, whether dysbiosis is the cause or the effect of chronic inflammation remains the subject of ongoing debate. Most human studies are cross-sectional, case-control studies that, by design, are not able to distinguish cause-and-effect from reverse causality. However, a well-designed prospective clinical study demonstrated the importance of microbial composition in the development of allergy (Abrahamsson et al. 2014). This study showed a strong correlation between low gut microbial diversity during infancy and an increased incidence of allergy later in childhood. In addition, animal models and longitudinal studies in children at risk of developing type 1 diabetes support the concept that loss of microbial diversity, rather than a specific microbial pathogen, has crucial functional relevance to human health and disease. This is mediated, at least in part, by interactions between lumenal microorganisms and host immune cells and epithelial cells lining the length of the gut (Honda and Littman 2016; Thaiss et al. 2016).

Major environmental factors thought to influence the development and stability of the gut microbiota include exposure to dietary constituents, and the use of antibiotics (Falony et al. 2016). For instance, the microbiota of a baby matures in a stepwise fashion that corresponds to shifts in dietary exposures. Whereas breastfeeding is characterized by a predominance of lactic acid-producing bacteria and Bifidobacteria, introduction of weaning shifts the gut microbiota to an adultlike community with a predominance of Bacteriodetes and Firmicute species. Coinciding with this nutritional shift, the host immune system develops and matures to reflect the maturing gut lumenal microbiota. This creates an early "window of opportunity" to prime developing infants with lasting education of the immune system and tolerance. Adults, on the other hand, despite having stable gut microbial communities, can still respond to changes in diets with rapid readjustments in the microbiota. Microbial taxa can spike within hours following a meal (David et al. 2014), but can also become permanently lost over generations with selective dietary pressures such as the depletion of nondigestible dietary fibers (Sonnenburg et al. 2016). Therefore, long-term dietary habits are critical in determining the gut microbiota composition across the lifespan which, in turn, leaves lasting impressions on host immunity and immune function.

Given the tri-partite interplay between host microbiota, immunity, and diet, growing interest now focuses on defining the functional consequences of manipulating microbial consortia to promote health (Baumler and Sperandio 2016; Gilbert et al. 2016). The gut microbiota is now widely accepted as a major factor at the intersection of diet and immunity, but mechanisms underlying these interactions and the bacterial metabolites that are involved are complex and only just now beginning to be unraveled. This literature review highlights selected advances related to the impact of gut microorganism-derived therapeutics on host immune functions. We have summarized previous studies and provide an overview of current research in this field.

\section{Dietary effects on host immune function via impacts on the gut microbiome}

Although microbial communities in humans are established early in life (Faith et al. 2013), dietary components, such as fats and sugars, elicit rapid short-term fluctuations in the microbial community. For example, changing fiber and fat macronutrient contents alters microbial diversity as early as the day after beginning intake, and both are known to influence the production of bacterial metabolites (David et al. 2014). Bacterial metabolites, including short-chain fatty acids (SCFA), 
catabolites of tryptophan metabolism, and omega-3 fatty acids, can activate G-protein coupled receptors present on gut epithelial and immune cells to mount anti-inflammatory responses. Conversely, depletion of select dietary substrates can, over time, result in a proinflammatory state in the intestinal environment. Besides altering microbial abundance, dietary exposures influence bacterial gene expression. For example, in a comparison between healthy human vegans and omnivores, while diet had a surprisingly modest impact on gut microbiota composition, the production of bacterial metabolites was divergent between the 2 groups and constrained by the composition of the existing microbiota (Wu et al. 2016). Therefore, diet elicits changes in both the composition and function of intestinal microbiota, but its ability to promote health and manage disease is still highly variable due to interpersonal differences in resident microbiota composition.

\section{Prebiotics}

Prebiotics are non-digestible dietary food ingredients that resist absorption and digestion so that they are able to transit to the distal small intestinal and colon mostly intact. Prebiotics have been described as "selectively fermented ingredients that allow specific changes, both in the composition and (or) activity in the gastrointestinal microflora that confers benefits upon host well-being and health" (Roberfroid 2007). Specific bacteria (such as Bifidobacteria and Lactobacillus species) possess degradation enzymes which enable prebiotic oligosaccharides to be utilized as a carbon source, thereby releasing SCFA as a by-product during bacterial fermentation. Common examples of prebiotics include plant-derived oligosaccharides, such as inulin and fructo-oligosaccharides (FOS). More complex galacto-oligosaccharides and short-chain trisaccharides (such as sialylactose or fucosyllactose) are present in human milk oligosaccharides (HMO) in maternal breast milk. The complexity of oligosaccharide structures vary by their sources: whereas inulin and FOS are linear $\beta(1-2)$ fructan polymers, HMOs are more branched, diverse, and abundant (roughly $4-5 \mathrm{~g} / \mathrm{L}$ ). HMOs, normally the first prebiotics ingested by humans, serve as substrates to promote the growth and activity of Bifidobacteria and lactic acid-producing bacteria in breastfed infants (Underwood et al. 2015).

Although the biological activities of prebiotics are believed to be similar to HMOs, there are functional differences. For example, HMO content in the breast milk of Malawian mothers correlates with the linear growth of the offspring. Mothers whose children exhibited stunting have lower levels of fucosylated and sialyated HMOs. When sialylated milk oligosaccharides are supplemented into the diets of mice and piglets exhibiting the phenotypes of severe malnutrition, gains in lean-body mass, and improvements in metabolic activity and bone growth are observed. These effects are absent with inulin-supplemented diets (Charbonneau et al. 2016). Divergent effects observed between various oligosaccharides are strongly linked to the structural requirement for sialic acid side-chains (Bode and Jantscher-Krenn 2012), which may yield variable microbial effects on nutrient metabolism. These effects are supported by differences observed in both circulating (serum) and liver metabolites. A recent study demonstrated that sialyated HMOs, but not GOS, protect against intestinal pathology in a neonatal rat model of necrotizing enterocolitis (Autran et al. 2016). In addition, a recent review article highlights the multifactorial effect of prebiotics and the diverse clinical outcomes when used to prevent necrotizing enterocolitis in very low birth weight infants (Johnson-Henry et al. 2016).

\section{Direct and indirect immunomodulatory effects of prebiotics}

Aside from structural specificity, prebiotic-mediated immune regulation is also influenced by the existing intestinal microbiota (Figure 1). For instance, a recent study by the DIABIMMUNE Study Group identified that the difference in HMO-metabolizing bacteria from children under 3 years of age results in completely different immune responses and endotoxin tolerance (Musilova et al. 2014; Vatanen et al. 2016). Whereas fecal samples from Finnish and Estonian children are highly abundant in Bacteroides species, those of the Russian children consist mostly of Bifidobacteria. Although both phyla are able to metabolize HMOs, the microorganisms lead to profound functional differences in the dominant microbial lipopolysaccharide (LPS) subtype being expressed by the gut microbiota. Finnish and Estonian children are characterized by Bacteroides-derived LPS, which lack immunogenicity in vitro and do not reduce the development of type 1 diabetes in NOD mice. In contrast, Russian children are characterized by Escherichia coli-derived LPS that has been shown to reduce the development of type 1 diabetes in NOD mice. These findings demonstrate that prebiotic-mediated immune regulation extends beyond the mere provision of substrates, and indicate that the 


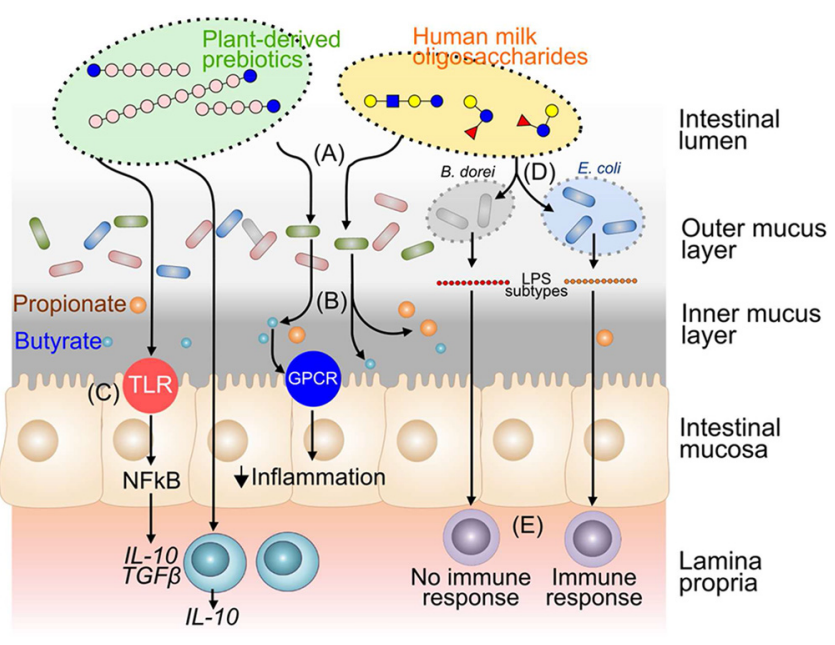

Figure 1: Mechanisms of action for prebiotic-mediated immune regulation. (A) Both plant- and human-derived oligosaccharides are metabolized by select gut communities to $(B)$ generate bacterial metabolites including SCFAs such as propionate and butyrate. SCFAs and other bacterial metabolites can activate GPCRs expressed on IECs to dampen host inflammatory responses. (C) Intact prebiotics may also directly activate Toll-like receptors expressed on IECs and host immune cells to induce the expression of antiinflammatory cytokines $I L-10$ and TGF $\beta$. (D) Bacterial communities (e.g., Bacteroides dorei versus Escherichia coli) metabolize HMOs to produce LPS subtypes with different immunogenicity on the host $(E)$. Human milk oligosaccharides (HMOs); G-protein-coupled receptors (GPCRs); interleukin 10 (IL-10); intestinal epithelial cells (IECs); lipopolysaccharide (LPS); short chain fatty acids (SCFAs); transforming growth factor beta (TGF $\beta)$.

observed effects on immune function largely relate to the nature and subtype of bacterial metabolites expressed by the resident gut microbiota. This concept could serve to explain why autoimmune diseases, like type 1 diabetes and allergic conditions, are more common in Finland than in Russia.

Apart from immune regulation via microbial interactions, growing evidence also highlights the potential for direct immune regulatory effects of prebiotic oligosaccharides. For instance, in vitro studies demonstrate that prebiotic exposure directly triggers cytokine and chemokine release in intestinal epithelial cells, monocytes, and dendritic cells (Lehmann et al. 2015). Similarly, our group observed that gut epithelial Caco2bbe cells cultured in the absence of microorganisms have increased expression of the anti-inflammatory cytokines interleukin (IL)-10 and transforming growth factor $\beta$ when exposed to prebiotic compounds (Johnson-Henry et al. 2014). Moreover, expression of pro-inflammatory cytokines tumor necrosis factor-alpha and CXCL8 (also referred to as IL-8) are reduced in epithelia pre-treated with prebiotics and then challenged with enterohemorrhagic Escherichia coli, serotype O157:H7, compared to exposure to the enteric pathogen in the absence of oligosaccharides.

Prebiotics have received considerable attention for their potential as fermentation substrates for intestinal bacteria, their ability to influence host health through effects on probiotic bacteria, and their impact on intestinal SCFA production (He et al. 2015; Vogt et al. 2015a; Correa-Oliveira et al. 2016). SCFA elaborated by gut microorganisms is a route through which dietmicrobiota interactions influence host immune activity, with effects demonstrated not only at the local mucosal level (Arpaia et al. 2013; Kim et al. 2013b; Smith et al. 2013), but also at lung mucosal surfaces and systemically (Maslowski et al. 2009; Trompette et al. 2014; Thorburn et al. 2015). Recent findings further reinforce the role of fermentable dietary substrates and SCFA produced by gut bacteria in regulating the immune system. Mice fed low fiber diets, with subsequent low levels of SCFA production, show defects in antibody production against the pathogen Citrobacter rodentium. This effect was reversed by elevating SCFA levels through the consumption of a diet containing $5 \%-15 \%$ pectin: inulin (Kim et al. 2016). SCFAs mediate their effects by accelerating $\mathrm{B}$ cell metabolism and by enhancing expression of genes involved in B cell differentiation to antibody-producing plasma cells. These effects are apparent in systemic as well as intestinal tissues, further reinforcing earlier evidence for system-wide effects of SCFAs produced by gut microorganisms. High-fiber diets in mice also promote oral tolerance by providing substrates for production of the SCFA acetate and butyrate, which act through G-protein-coupled receptor (GPR)43 and GPR109A to enhance retinaldehyde dehydrogenase (RALDH) activity in tolerogenic $\mathrm{CD} 103^{+}$ dendritic cells (DC), in turn promoting Treg induction in both the intestinal submucosa and in mesenteric lymph nodes (Tan et al. 2016). Increased immunoglobulin A (IgA) production and protection against food allergy is also associated with SCFA production resulting from a high fiber diet. The SCFA-mediated impact on DC and Treg induction requires sufficient dietary vitamin A to support RALDH activity, suggesting that interactions with other dietary components are important to consider with respect to microorganism- and diet-based therapeutics. 
Increasing evidence points to roles for other gut microbial metabolites in modulating immune measures and influencing host defences in the mucosa and systemically (Wikoff et al. 2009; Zelante et al. 2013; Hubbard et al. 2015; Vogt et al. 2015b). While SCFAs are the best characterized microbial metabolites, determining the ability of other gut microorganism-derived metabolic mediators to influence host immune activity will contribute to a better understanding their therapeutic potential.

Several prebiotics such as FOS, GOS, $\beta-1,4-$ Mannobiose, and resistant starches act as ligands for specific Toll-like receptors (TLR), suggesting a mechanism for direct interactions with cell types participating in innate immune activity (Kovacs-Nolan et al. 2013; Bermudez-Brito et al. 2014; Ortega-Gonzalez et al. 2014; Lehmann et al. 2015), a mode of action distinct from the effects traditionally associated with prebiotics. These interactions include TLR-4-mediated effects of FOS and GOS on IL-10 production by human monocyte-derived dendritic cells (DC) (Lehmann et al. 2015), FOS on proinflammatory cytokine production and NF- $\kappa \mathrm{B}$ activation in human intestinal epithelial cells (IEC) (OrtegaGonzalez et al. 2014) and in human and rat monocytes (Capitan-Canadas et al. 2014), as well as TLR-2mediated impact of short chain $\beta 2 \rightarrow 1$ fructans on human IEC barrier integrity (Vogt et al. 2014). Involvement of peroxisome proliferator-activated receptors (PPAR) has also been reported, including PPAR $\gamma$ activation by FOS mediated through the peptidoglycan recognition protein 3 (PGlyRP3) expressed on human IEC (Zenhom et al. 2011). These interactions add further complexity to the interpretation of the impact of prebiotics on the immune system, in the context of gut microorganism-derived therapeutics.

\section{Host specific factors influencing prebiotic modulation of the immune system}

While current evidence for direct and indirect mechanisms of action for both prebiotics and probiotics is rapidly accumulating, many questions remain to be answered; factors such as health, age, and gender may influence host responses. For example, the impact of prebiotics in healthy human adults may differ from that observed in disease states. Recent studies have detected a relatively minor impact on immune measures in healthy individuals in either the absence (Lomax et al. 2012; Clarke et al. 2016) or in the presence of an immune challenge (Lomax et al. 2015).
Host sex may be another necessary factor to consider in evaluating the potential applications of prebiotics. For example, sex-associated differences in the impact of oligofructose-supplemented diets on IgA production and on fecal microbial community structure indicate differences in metabolism of this prebiotic between microbial communities of male and female rats (Shastri et al. 2015). Use of a weaning diet high in prebiotic fiber to mitigate effects of maternal protein restriction in rats leads to reduced insulin resistance in male offspring. However, increased plasma endotoxin levels and decreased colonic tight junction protein expression in female offspring, indicates sex-specific effects of a prebiotic-supplemented diet on intestinal epithelial barrier integrity (Hallam and Reimer 2014). Overall, these findings indicate that sex is also a factor to consider in the potential efficacy of gut microorganism-based therapeutics.

Compared to inulin, sialylated bovine milk oligosaccharides promote larger weight gain in both mice and piglets with humanized gut microbiota originally obtained from an infant in Malawi, Africa suffering from impaired linear growth due to nutritional deprivation and environmental enteropathy (Charbonneau et al. 2016). This effect was observed in animals fed a Malawi-like diet and relates to variable gut microbial effects on nutrient metabolism, as demonstrated by changes in both circulating (serum) and liver metabolites.

\section{Probiotics}

Probiotics are "live microorganisms that, when administered in adequate amounts, confer health benefits on the host" (Hill et al. 2014) by enhancing gut epithelial barrier integrity, reversing pathogeninduced signal transduction, and boosting the host immune system (Figure 2) (Sanders et al. 2013). We have shown that a commercial mixture of lactic-acid producing bacteria (L. helveticus Rosell-52 and L. rhamnosus Rosell-11) ameliorates the severity of C. rodentium-induced colitis in both adult and newborn mice (Johnson-Henry et al. 2005; Gareau et al. 2010). The results of these animal studies provide the basis for a randomized clinical trial regarding the efficacy of the probiotic mixture in children attending hospital emergency departments with acute enteritis that is now underway in centers across North America (Freedman et al. 2014). 


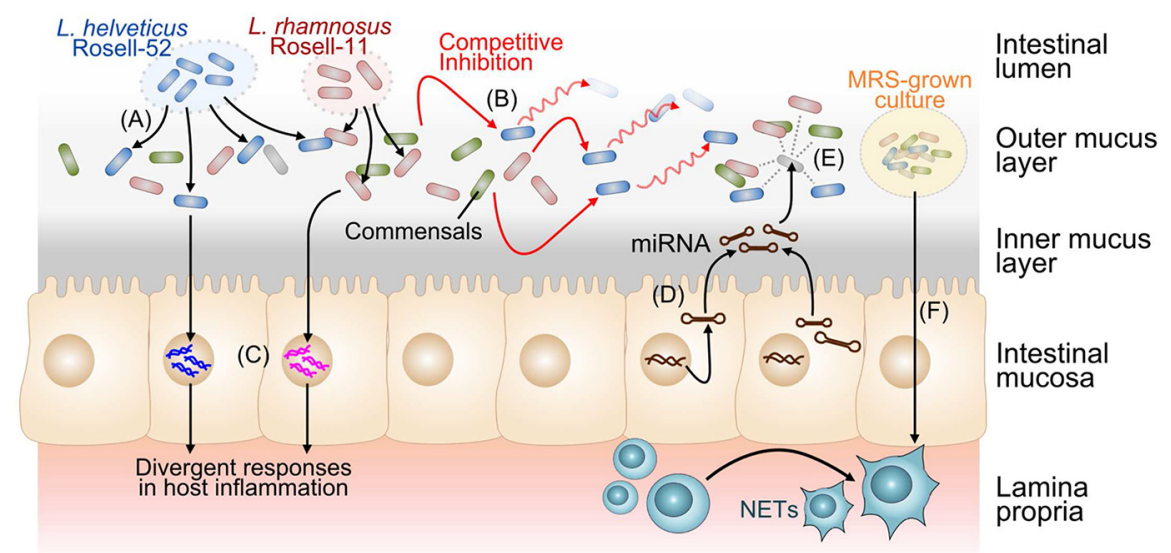

Figure 2: Mechanisms of action for probiotic-mediated immune regulation. (A) Probiotics are transiently present in the host GI tract. (B) Existing commensals can outcompete probiotics once consumption stops. Nevertheless, (C) probiotics may induce distinct, species-specific inflammatory responses in host IECs. (D-E) Host cells such as IECs secrete miRNAs into the lumen that can enter bacterial cells to facilitate interspecies changes in microbial composition and function. (F) Probiotic strains grown in select culture conditions such as MRS can alter immune cell function such as the formation of neutrophil extracellular traps to affect host inflammatory responses. De Man, Rogosa and Sharpe (MRS); gastrointestinal tract (GI); intestinal epithelial cells (IECs); neutrophil extracellular traps (NETs).

More recently, we demonstrated that fecal pellets from healthy adult mice cultured in de Man Rogosa Sharpe (MRS) broth, to enrich for Lactobacilli, reduces the severity of $C$. rodentium-induced colonic epithelial injury. This reduction in infection was associated with lower mRNA levels of IFN- $\gamma$ and TNF- $\alpha$ in mucosal homogenates, and with decreased production of neutrophil extracellular traps (mesh-like structures that function to contain and kill bacteria) (Vong et al. 2015). These findings are entirely consistent with the emerging concept that both beneficial microorganisms and enteric pathogens have evolved strategies over time to manipulate the host innate and adaptive immune system (Coyte et al. 2015; Ayres 2016; Fischbach and Segre 2016).

\section{Interactions of probiotics with the immune system}

Most microorganisms characterized as probiotics are Gram-positive bacteria belonging to the Bifidobacteria and Lactobacilli genus. However, Gram-negative Escherichia coli strain Nissle 1917, the yeast Saccharomyces boulardii and a variety of other microorganisms also have been reported to have probiotic properties. Probiotics generally transiently colonize the gut of older children and adults only during the period of when they are being regularly ingested, and disappear from the colonic microbiota soon after ingestion is stopped; likely via extrusion by competitive inhibition from the normal commensal microbiota (Zhang et al. 2016). Although it appears as though probiotics are able to mediate beneficial effects without a discernible impact on the overall composition of the fecal microbiota (Kristensen et al. 2016), this may not be too surprising since there is good evidence that simply describing numbers of bacteria present in a microbial community does not by itself predict biological impact and functional outcomes (Rolig et al. 2015).

Probiotic strains mediate beneficial effects against the risk of pathogenic infections by colonization resistance, enhancing epithelial barrier integrity, and by impacting on host adaptive and innate immunity (Hardy et al. 2013). To date, the impact of probiotic bacteria on innate immunity has been demonstrated through effects on cell signaling pathways, which are mediated through both direct and indirect interactions (Table 1). Immunochipbased microarray analysis reveals that signaling responses to probiotic bacteria are strain-specific (Ho et al. 2013). This study demonstrated that L. helveticus strain Rosell-52 and L. rhamnosus strain GG induce very different immune responses in cultured gut-derived epithelia (Caco2-bbe cells), when used to prevent E. coli enteric infection. 
Table 1: Examples of various immunomodulatory mechanisms of probiotics.

\begin{tabular}{|c|c|c|c|c|}
\hline Probiotic & In vitro cell model & Immunomodulatory activity & Mechanism of action & Reference \\
\hline $\begin{array}{l}\text { Lactobacillus reuteri } \\
\text { CRL1098 }\end{array}$ & PBMC & $\begin{array}{l}\text { Down-regulation of } T N F-\alpha \\
\text { production }\end{array}$ & $\begin{array}{l}\text { Activation of ERK and } \\
\text { p38 MAPK pathways }\end{array}$ & $\begin{array}{l}\text { Mechoud } \\
\text { et al. } 2012\end{array}$ \\
\hline $\begin{array}{l}\text { Bifidobacterium breve and } \\
\text { Steptococcus thermophiles }\end{array}$ & $\begin{array}{l}\text { PBMC and THP-1 } \\
\text { human monocytes }\end{array}$ & $\begin{array}{l}\text { Down-regulation of LPS-induced } \\
T N F-\alpha \text { production }\end{array}$ & $\begin{array}{l}\text { Reduced LPS-FITC } \\
\text { binding and inhibition } \\
\text { of NF-KB }\end{array}$ & $\begin{array}{l}\text { Menard et al. } \\
2004\end{array}$ \\
\hline \multirow[t]{2}{*}{ Lactobacillus plantarum } & $\begin{array}{l}\text { THP-1 human } \\
\text { monocytes }\end{array}$ & $\begin{array}{l}\text { Down-regulation of LPS-induced } \\
\text { TNF- } \alpha \text { production }\end{array}$ & $\begin{array}{l}\text { Inhibition of the } \\
\text { phosphorylation of } \\
\text { ERK, JNK, p38 } \\
\text { kinase }\end{array}$ & $\begin{array}{l}\text { Kim et al. } \\
2008\end{array}$ \\
\hline & & & $\begin{array}{l}\text { Inhibition of the } \\
\text { degradation of } І \kappa \beta \alpha \\
\text { and } \operatorname{I\kappa }_{\kappa \beta}\end{array}$ & \\
\hline $\begin{array}{l}\text { Lactobacillus helveticus } \\
\text { R0052, Bidifobacterium } \\
\text { longum subsp. infantis } \\
\text { R0033, and Bifidobacterium } \\
\text { bifidum R0071 }\end{array}$ & HT-29 human IECs & $\begin{array}{l}\text { Attenuation of poly (I:C)-induced } \\
\text { pro-inflammatory gene } \\
\text { expression }\end{array}$ & $\begin{array}{l}\text { Modulation of TRIF, } \\
\text { MAPK, and NF-kB } \\
\text { signaling pathways }\end{array}$ & $\begin{array}{l}\text { Macpherson } \\
\text { et al. } 2014\end{array}$ \\
\hline $\begin{array}{l}\text { Lactobacillus acidophilus } \\
\text { NCFM }\end{array}$ & $\begin{array}{l}\text { Human PBMC-derived } \\
\text { DCs and CD45RA }{ }^{+} / \\
\text {CD4 }{ }^{+} T \text { cells }\end{array}$ & $\begin{array}{l}\text { Increased production of IL-10 by } \\
\text { DCs leading to an increase in } \mathrm{T} \\
\text { cell polarization to Th2 } \\
\text { phenotype }\end{array}$ & $\begin{array}{l}\text { Interaction of S layer } \\
\text { protein A with DC- } \\
\text { SIGN on DCs }\end{array}$ & $\begin{array}{l}\text { Konstantinov } \\
\text { et al. } 2008\end{array}$ \\
\hline $\begin{array}{l}\text { Bifidobacterium longum } \\
\text { BB536 and Bifidobacterium } \\
\text { breve M-16 V }\end{array}$ & $\begin{array}{l}\text { Porcine intestinal } \\
\text { epithelial }\end{array}$ & $\begin{array}{l}\text { Down-regulation of } I L-8, M C P-1 \text {, } \\
\text { and } I L-6 \text { in response to challenge } \\
\text { with heat-killed enterotoxigenic } \\
\text { Escherichia coli }\end{array}$ & $\begin{array}{l}\text { Modulation of NF-kB } \\
\text { and MAPK pathways } \\
\text { via increased } \\
\text { transcription of A20 }\end{array}$ & $\begin{array}{l}\text { Tomosada } \\
\text { et al. } 2013\end{array}$ \\
\hline
\end{tabular}

While IEC and antigen-presenting cells (APC) are key innate immune participants, their activity have downstream effects on adaptive immunity. Moreover, APC interactions with T cells are essential for a successful adaptive immune response. Direct interaction of bacteria and their products with IECs provide one potential route for host-microorganism interaction at the gut mucosal interface and in gut-associated lymphoid tissues (GALT). Commensal and probiotic bacteria modulate IEC activity which, in turn, allows IEC to influence key cells of the immune system, including dendritic cells, macrophages, and intraepithelial lymphocytes (Lebeer et al. 2010; Peterson and Artis 2014). Inhibition of NF- $\mathrm{KB}$ activation in IEC by commensal gut bacteria was initially observed with specific commensal enteric Salmonella strains (S. typhimurium PhoPc and S. pulloram), which are able to inhibit nuclear translocation of the DNA-binding protein $N F-\kappa B$, by inhibiting IkB- $\alpha$ ubiquitination, thus blocking IkB- $\alpha$ degradation and release of NF- $\kappa B$ from this inhibitory complex (Neish et al. 2000). Inhibition of NF- $\kappa \mathrm{B}$ activation induced by a variety of proinflammatory signals has since been reported for several probiotic strains, including $L$. acidophilus, L. reuteri ATCC PTA 6475, L. casei, L. rhamnosus strain GG, and Bifidobacterium longum, (Bai et al. 2004; Tien et al. 2006; Iyer et al. 2008; Kim et al. 2008; Nandakumar et al. 2009) as well as several other species of Bifidobacterium (Riedel et al. 2006). This mechanism down-regulates expression of pro-inflammatory cytokines and mediators, such as the chemokine IL-8, and is postulated to play a role in the ability of the IEC to cope with the high load of commensal bacteria present in the distal portions of the human intestinal tract. Disruption in the host gut microbiota would undermine this balance. This concept is a driving theory behind trials testing the role of gut microorganisms and the potential for probiotic therapy in chronic inflammatory bowel diseases.

Several strains of probiotics are reported to down-regulate pro-inflammatory gene expression and cytokine production by human IEC. The ability to block NF- $\kappa B$ activation fits with this mode of action. Down-regulation of IL-8 production has been used as a marker for potential anti-inflammatory activity, and several probiotic strains have been reported to have this ability, including B. longum strain Rosell-175, L. bulgaricus strain Rosell-52, L. rhamnosus strain Rosell-11, L. reuteri, L. rhamnosus strain GG, 
L. plantarum, L. acidophilus Bar13, B. longum Bar33, B. longum NCC2704, B. breve BbrY and B. bifidum strains S17 and BbiY, B. infantis and L. salivarius (McCracken et al. 2002; Bai et al. 2004; Ma et al. 2004; O'Hara et al. 2006; Riedel et al. 2006; Ko et al. 2007; Candela et al. 2008; Imaoka and Umesaki 2009; Nandakumar et al. 2009; Wagar et al. 2009). In addition, a blend of probiotic strains (L. helveticus Rosell-52, B. longum subsp infantis R033 and B. bifidum Rosell-71) attenuates TLR3-mediated pro-inflammatory gene expression in HT-29 human IEC by modulating mitogen-activated protein kinase (MAPK) and NF- $\mathrm{kB}$ signaling pathways (Macpherson et al. 2014). Comparative transcription profiling of the impact of IEC co-culture with a range of individual probiotic strains to that of several pathogens indicates differential regulation of MAPK signaling (Audy et al. 2012), as well as modulation of immuneassociated genes by L. helveticus strain Rosell-52. In keeping with these findings, we observed that soy fermented with $L$. helveticus strain Rosell-52 downregulates NF- $\mathrm{KB}$-mediated gene expression induced in human IEC in response to TNF- $\alpha$ (Lin et al. 2016), suggesting this substrate may provide a useful vehicle for probiotic delivery in the diet.

Numerous studies have been conducted to further delineate the mechanisms of action behind the ability of certain probiotics to block NF- $\kappa \mathrm{B}$ expression in IEC. Many of these studies focus on negative regulators of the innate immune system. For example, L. crispatus M247 induces PPAR $\gamma$ activation in IEC through $\mathrm{H}_{2} \mathrm{O}_{2}$ production (Voltan et al. 2008). PPAR $\gamma$ is a nuclear receptor that inhibits NF- $\kappa \mathrm{B}$ activation, plays an anti-inflammatory role, and provides other mechanistic routes for probiotics to act on IEC. A similar effect is reported for $L$. casei in the context of LPS-induced gene expression, with upregulation of PPAR $\gamma$ mRNA, and down-regulation of $I L-8$, cyclooxygenase (COX)-2, and TLR-4 expression (Eun et al. 2007). Orally administered probiotics also protect against sepsis-induced liver and colonic damage in mice through activation of PPAR $\gamma$ (Ewaschuk et al. 2007).

Recent evidence indicates that some probiotic strains down-regulate pro-inflammatory biomarkers via increased expression of the A20 protein (O'Callaghan et al. 2012; O'Flaherty and Klaenhammer 2012; Villena et al. 2012; Tomosada et al. 2013). A20 is responsible for termination of the pro-inflammatory NF- $\kappa \mathrm{B}$ signaling pathway and TNF- $\alpha$-induced apoptosis. Increased A20 expression effectively down-regulates subsequent expression of pro-inflammatory biomarkers at the transcriptome level by terminating the transcriptional activ-

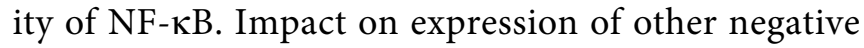
regulators of pro-inflammatory signaling has also been reported, including upregulation of Single immunoglobulin interleukin-2 receptor-related (SIGIRR) and Tollip in immature human enterocytes by a secreted product of B. infantis (Ganguli et al. 2013). Upregulation of A20, Bcl-3, Tollip, and SIGIRR in porcine IEC by $B$. breve MCC-117 has also been demonstrated (Murata et al. 2014), suggesting this may be a general mechanism by which multiple probiotic strains modulate IEC gene expression.

\section{Epigenetic and post-transcriptional effects of probiotics on gene expression}

Recently identified modes of action of probiotics on IEC and other cells involve epigenetic and posttranscriptional modifications, leading to changes in expression of genes involved in the immune response. One such mechanism involves the differential induction of microRNAs (miRNAs). Demont et al. (2016) recently demonstrated that $L$. paracasei NCC 2461 regulates miRNA and increases anti-inflammatory effects in peripheral blood mononuclear cells. This effect was attributed to a decrease in the levels of miR-27a, a miRNA involved in the regulation of $I L-10$ expression, in response to treatment with heat-treated $L$. paracase $i$ NCC 2461. It is also clear that interactions between the host immune system and lumenal microorganisms are bidirectional in nature. For instance, a recent study demonstrated that host mRNA secreted by intestinal epithelial cells via exosomes is present in feces and acts to mediate inter-species redistribution of the gut microbiota composition and function (Liu et al. 2016). These investigators also showed that fecal miRNA can enter viable bacteria, bind to bacterial DNA, and regulate gene transcription to promote bacterial growth and replication. A recent study by Zhou et al. (2015) demonstrated induction of miRNA by soluble mediators produced by a probiotic. Rat IEC-6 IECs treated with cell-free supernatant from Bifidobacterium infantis showed an increase in the expression of miR-146a, a miRNA involved in the post-translational modification of genes involved in the inflammatory immune response, following challenge with LPS.

Interactions of probiotics with IEC and APC mediated through other epigenetic mechanisms have also 
been reported. For example, B. breve DSMZ 20213 and L. rhamnosus strain GG reduce histone deacetylation and enhance DNA methylation in LPS-challenged HT29 IEC, in concert with decreased nuclear translocation of NF- $\mathrm{KB}$ and decreased expression of $I L-17$ and $I L-23$ (Ghadimi et al. 2012). Inhibition of histone deactylation (Hdac) is a well-documented epigenetic mechanism through which the SCFA butyrate mediates changes in expression patterns of genes involved in immune responses (Fusunyan et al. 1999; Thorburn et al. 2015; Correa-Oliveira et al. 2016). While butyrate is mainly a product of gut microorganisms other than Lactobacilli, other metabolic products, including lactic acid, also possess histone deacetylase inhibitor (HDAC) inhibitory activity (Latham et al. 2012; Garrote et al. 2015), suggesting this mechanism is another important route through which probiotics modulate the activity of IEC and APC.

\section{Immunomodulation of monocytes and macrophages by probiotics}

Numerous studies have explored interactions between probiotic bacteria and other cell types involved in both innate and adaptive immunity. While many recent studies focus on the role of probiotics in immune homeostasis, some probiotic strains interact with monocytes and macrophages to elicit an immunostimulatory effect. For example, the probiotic mixture VSL\#3 activates NF- $\kappa \mathrm{B}$ in macrophages resulting in increased production of IL- 6 and IL-12, an effect mediated by TLR-9 recognition of DNA derived from these probiotic strains (Rachmilewitz et al. 2004). L. rhamnosus strain GG induces NF- $\kappa \mathrm{B}$ activation and expression of IL-6 in human peripheral blood mononuclear cells (Miettinen et al. 2000) and decreases LPS Additionally, LGG induces TNF- $\alpha$ production by human THP-1 macrophages by inducing STAT3 activation. This leads to inhibition of c-Jun-N-terminal kinase (JNK) activation and induction of granulocyte-Colony Stimulating Factor (G-CSF), which, in turn, inhibits TNF- $\alpha$ production (Kim et al. 2006). This effect is also mediated by culture supernatants from L. rhamnosus strain GG and L. rhamnosus GR-1 (Kim et al. 2006). Supernatants derived from $L$. rhamnosus strain GG also increase both TNF- $\alpha$ and IL-10 production by RAW265.7 murine macrophages, with effects mediated through TLR-2 and NOD2 (Harb et al. 2013). Conditioned media from L. rhamnosus strain GG upregulates TLR-1, -4, -5, -6, $-7,-8$, and -9 expression by human blood-derived macrophages and dendritic cells, as well as MHC class
II expression by macrophages, suggesting an impact on both innate recognition and antigen presentation efficiency by these APC (Fong et al. 2016).

Probiotics also modulate macrophage phenotype and activity. Tissue macrophages exist as a heterogeneous population, broadly categorized into M1 and M2 macrophages. M1, or classically activated macrophages, are closely associated with the development of many inflammatory diseases, and secrete proinflammatory cytokines such as IL- $1 \beta$, IL- 6 , and TNF- $\alpha$. In contrast, M2 macrophages, or alternatively activated macrophages, play a regulatory and antiinflammatory role through the secretion of the regulatory cytokines IL-10 and IL-1Ra. Macrophages exhibit phenotype plasticity, as they are able to switch between M1 and M2 depending upon external stimuli (Martinez and Gordon 2014). Treatment of non-differentiated macrophages with the probiotic mixture VSL\#3 results in an increase in the regulatory cytokines $I L-1 R a, I L-13$, epidermal growth factor $(E G F)$, fibroblast growth factor-2 (FGF-2), transforming growth factor (TGF)- $\alpha$, vascular endothelial growth factor $(V E G F)$, as well as pro-inflammatory cytokines, including $I L-12$ and TNF- $\alpha$ suggesting differentiation into the immunoregulatory M2b macrophage phenotype (Isidro et al. 2014). Gram-negative bacteria, such as species of Escherichia and Salmonella, are more potent inducers of M1 activation than Gram-positive bacteria, with strain-specific effects observed (Christoffersen et al. 2014). A fermented milk product containing L. paracasei FT700 induces differentiation of monocytes into immunoregulatory macrophages (Tulini et al. 2015), suggesting a possible mechanism of action for a probiotic functional food. A comparison of the impact of 5 strains of heat-killed probiotics and their secreted proteins on LPS-induced TNF- $\alpha$ and IL- 6 production by THP-1-derived M1 and M2 macrophages reveals differential effects, depending on formulation and on macrophage subtypes (Habil et al. 2011). For example, secreted proteins and heat-killed strains of Bifidobacterium and Lactobacillus suppress IL-6 production by M2 macrophages, but differ in their impact on M1 macrophages. Production of the pro-inflammatory cytokine TNF- $\alpha$ is augmented by both formulations in CD14 ${ }^{\text {hi }}$ M1 macrophages, reflecting the complexity of probiotic-APC interactions in vivo, and demonstrating the importance of considering probiotic formulations in potential therapeutic applications. 


\section{Dendritic cell and $\mathrm{T}$ cell responses to probiotics}

The effects of probiotic and commensal organisms on dendritic cell (DC) differentiation and subsequent interactions with $\mathrm{T}$ cells have garnered considerable attention. Oral supplementation with L. rhamnosus results in $\mathrm{T}$ cell hyporesponsiveness in cohorts of healthy volunteers and in subjects with Crohn's disease. The effect is mediated via DC-T cell interactions resulting in decreased $\mathrm{T}$ cell proliferation and attenuation of IL-2 and IL-4 production from CD3/CD28-stimulated $\mathrm{T}$ cells, suggesting a probiotic-DC interaction inducing hypo-responsive $\mathrm{T}$ cells as an approach to modulating host immunity (Braat et al. 2004). Other studies indicate a role for probiotics in DC conditioning to a regulatory phenotype. DC isolated from the mesenteric lymph nodes of patients with colitis have increased transcription and production of IL-10 following in vitro culture with either L. salivarius UCC118 or B. infantis 3562 (O’Mahony et al. 2006). Comparison of cytokine profiles induced in mesenteric lymph nodes and peripheral blood mononuclear cell (PBMC)-derived DC by these probiotics and the pathogen Salmonella typhimurium UK1 reveal differences in the responses of DC from mucosal and systemic compartments, with PBMC-derived DC producing the pro-inflammatory cytokines IL-12 and TNF- $\alpha$ when cultured with Lactobacilli or Salmonella. In contrast, only Salmonella induces IL-12 production by MLN-derived DC, demonstrating that the DC source and tissue compartment are factors to consider in interactions of probiotics with APC. In another study, increased circulating blood levels of the immunoregulatory cytokine IL-10 were observed following oral administration of $B$. infantis 35624 to human volunteers, resulting in an increase in DC-mediated induction of Foxp3 expression in T cells (Konieczna et al. 2012). Conditioning of DC to this regulatory profile is linked to distinct effects of $B$. infantis on different DC phenotypes. While $B$. infantis induces both myeloid DC (mDC) and plasmacytoid DC (pDC) to express indoleamine 2,3-dioxygenase (IDO) and the regulatory cytokine $I L-10$, this effect is dependent on TLR-9 in $\mathrm{pDC}$, and TLR-2/6 in $\mathrm{mDC}$, suggesting differences in the mode of interaction of this probiotic with distinct DC phenotypes.

Retinoic acid is also involved in Treg induction and $B$. infantis induces RALDH expression in mDCs, requiring the involvement of TLR-2 and DC-specific intercellular adhesion molecule-3-grabbing non-integrin
(DC-SIGN), a C-type lectin. In contrast, IDO expression is induced in pDCs by B. infantis via TLR-9, further demonstrating differential interactions with these APC, as well as a role for probiotic-mediated impact on cellular metabolic pathways involved in immune tolerance and regulation. Interactions of Lactobacilli with monocyte-derived human DC via DC-SIGN and their role in DC conditioning to induce Treg differentiation and IL-10-production have been demonstrated (Smits et al. 2005), in keeping with the ability of signaling through DC-SIGN to induce DC to a tolerogenic phenotype (Geijtenbeek and Gringhuis 2009; van Baarlen et al. 2013). This DC-SIGN-mediated effect on DC activity is observed with $L$. reuteri and $L$. casei, but not L. plantarum, suggesting that the involvement of DC-SIGN for probiotic-DC interactions is bacterial strain-specific. The involvement of varied PRRs in probiotic DC-interactions is further illustrated by the ability of cell-free supernatants of L. rhamnosus CNCM I-4036 to down-regulate pro-inflammatory cytokine production by E. coli-challenged DC, in a process involving TLR-1, TLR-9, and TLR-5-mediated signaling (Bermudez-Brito et al. 2014).

In addition to differences in cell surface molecules involved in probiotic-DC interactions, recent findings indicate novel mechanisms for their impact and provide further insight into species- and strain-based differences. Comparison of interactions of L. rhamnosus JB-1 with human monocyte-derived DC with effects of L. murinus, a strain lacking immunomodulatory activity, reveal distinct differences in the kinetics of internalization and intracellular processing, which may be involved in determining the outcome of contact of these APC with probiotics (Konieczna et al. 2015). The more slowly processed $L$. rhamnosus JB-1 is less effective at inducing co-stimulatory molecule expression and cytokine secretion, and DC primed with these bacteria preferentially induce Foxp3 expression in lymphocytes. This indicates a DC phenotype associated with the promotion of regulatory immune activity.

Regulatory miRNA-mediated activity may be another mechanism through which probiotics interact with host cells, with distinct differences between strains. Heatinactivated L. rhamnosus strain GG and $L$. delbrueckii subsp. bulgaricus down-regulate TLR-4 expression by human monocyte-derived DCs, and both strains modify regulatory miRNA expression, with differences apparent in both miRNA expression patterns and cell 
signaling profiles (Giahi et al. 2012). L. rhamnosus strain GG down-regulated expression of p38 and miR-146a but up-regulated miR-155. This is a pattern that is in keeping with the impact of this strain on TLR- 4 and $p 38$ expression. In contrast, L. delbrueckii subsp. bulgaricus decreases $\mathrm{I} \kappa \mathrm{B}$ expression (which is unaffected by L. rhamnosus strain GG), and does not influence miR-146a or miR-155 expression, indicating differences in mechanisms of action of different probiotics at the epigenetic level. As miR155 also down-regulates DC-SIGN expression (MartinezNunez et al. 2009), and DC-SIGN-mediated interactions of certain probiotics and DC phenotypes have been demonstrated, this suggests a novel route through which one bacterial strain could modulate responsiveness to another. This is a factor to consider in the design of probiotic-based precision therapeutics and potentially for probiotic activity in the context of the gut microbiota.

\section{Probiotic-derived bioactive components}

Although multi-strain probiotic formulations need careful consideration in the development of therapeutic approaches, given the diversity of mechanisms of interaction of probiotics with cells of the immune system, increasing evidence for roles of soluble, bioactive mediators produced by some strains warrants careful consideration (Table 2). For example, both probiotic formulation and host inflammatory state influence probiotic efficacy in an acute colitis model comparing live and heat inactivated Bifidobacterium breve NCC2950 and soluble mediators from conditioned media administered at different time points (Hayes et al. 2014). While direct interactions of probiotics with IEC and other cell types of the immune system have been intensively studied, there is a growing body of literature suggesting that probiotics also secrete or release an array of bioactive molecules with immunomodulatory activity (Hemarajata and Versalovic 2013; Ruiz et al. 2014). These bioactive molecules include, but are not limited to, cell structural components (lipoteichoic acid (LTA) and exopolysaccharides (EPS)), peptides (secreted or shed, including lactocepins), metabolic products such as polyphosphates, lactic acid, tryptophan metabolites, histamine, and quorum sensing molecules.

\section{Immunomodulatory activity of structural components, secreted proteins, and peptides}

LTA is a major constituent of the cell walls of Grampositive bacteria and regulates the activity of cell wall hydrolases involved in bacterial cell replication. LTA is liberated and secreted by certain Gram-positive bacteria during replication, or bacteriolysis caused by $\beta$-lactam antibiotics (Ginsburg 2002). Once liberated, LTA is recognised by members of the innate immune system through TLR-2 with cluster of differentiation (CD) 14 and CD36 acting as co-receptors. Usually LTA binds to TLR-2 and induces an increase in the transcription of the pro-inflammatory cytokines IL-1, IL-5, IL-6, and IL-8 (Ginsburg 2002). However, recent findings indicate that the immunogenic properties of LTA are speciesdependant, and vary depending on certain structural features (Lebeer et al. 2012). For example, LTA isolated from Staphylococcus aureus is highly immunostimulatory, resulting in increased transcription of many

Table 2: Lactobacilli produce a range of soluble mediators with immunomodulatory activity.

\begin{tabular}{|c|c|c|c|c|}
\hline Probiotic & Soluble mediator & Model system & Immunomodulatory activity & Reference \\
\hline $\begin{array}{l}\text { Lactobacillus } \\
\text { plantarum }\end{array}$ & Lipoteichoic acid & HT-29 Human IECs & $\begin{array}{l}\text { Down-regulation of TNF- } \alpha \text {-induced } \\
\text { pro-inflammatory cytokine production }\end{array}$ & Kim et al. 2012 \\
\hline $\begin{array}{l}\text { Lactobacillus } \\
\text { plantarum N14 }\end{array}$ & Exopolysaccharide & Porcine IECs & $\begin{array}{l}\text { Attenuation of the inflammatory response } \\
\text { to enterotoxigenic } E \text {. coli }\end{array}$ & $\begin{array}{l}\text { Murofushi et al. } \\
2015\end{array}$ \\
\hline $\begin{array}{l}\text { Lactobacillus reuteri } \\
\text { and Lactobacillus } \\
\text { johnsonii }\end{array}$ & Indole-3-aldehyde & $I d o 1^{-/}$mice & $\begin{array}{l}\text { Resistance to colonization by Candida } \\
\text { albicans SC5314 via induction of IL-22 }\end{array}$ & $\begin{array}{l}\text { Zelante et al. } \\
2013\end{array}$ \\
\hline $\begin{array}{l}\text { Lactobacillus } \\
\text { paracasei }\end{array}$ & Lactocepin & $\begin{array}{l}\text { Mouse model of } \\
\text { colitis }\end{array}$ & $\begin{array}{l}\text { Selective degradation of the } \\
\text { pro-inflammatory chemokine } I P-10\end{array}$ & $\begin{array}{l}\text { von Schillde et al. } \\
2012\end{array}$ \\
\hline $\begin{array}{l}\text { Lactobacillus reuteri } \\
\text { ATCC PTA } 6475\end{array}$ & Histamine & $\begin{array}{l}\text { THP-1 Human } \\
\text { monocytes }\end{array}$ & $\begin{array}{l}\text { Down-regulation of TLR-2-induced } \\
\text { TNF- } \alpha \text {-production }\end{array}$ & $\begin{array}{l}\text { Thomas et al. } \\
2012\end{array}$ \\
\hline $\begin{array}{l}\text { Lactobacillus } \\
\text { rhamnosus GG }\end{array}$ & $\mathrm{N}$-formyl methionine & $\begin{array}{l}\text { SK-CO15 Human } \\
\text { IECs }\end{array}$ & Generation of reactive oxygen species & $\begin{array}{l}\text { Wentworth et al. } \\
2011\end{array}$ \\
\hline $\begin{array}{l}\text { Lactobacillus } \\
\text { rhamnosus GG }\end{array}$ & $\begin{array}{l}\mathrm{p} 75 \text { and } \mathrm{p} 40 \\
\text { secreted proteins }\end{array}$ & $\begin{array}{l}\text { Young adult mouse } \\
\text { colon and mouse } \\
\text { colon epithelial cells }\end{array}$ & $\begin{array}{l}\text { Inhibition of TNF- } \alpha \text {-induced epithelial cell } \\
\text { apoptosis }\end{array}$ & Yan et al. 2007 \\
\hline
\end{tabular}


pro-inflammatory cytokines including TNF- $\alpha$ (Schroder et al. 2003). In contrast, LTA isolated from Lactobacillus plantarum down-regulates TNF- $\alpha$ induced pro-inflammatory cytokine transcription in vitro. Such inhibition is mediated through a TLR-2-dependant mechanism, resulting in inactivation of the NF- $\mathrm{B}$ signaling pathway (Kim et al. 2012). Furthermore, LTA isolated from L. plantarum has the ability to down-regulate LPS-induced inflammation in vitro and atherosclerotic plaque formation in vivo in $\mathrm{ApoE}^{-1-}$ mice by modulating the expression of proinflammatory cytokines and cell surface receptors (Kim et al. 2013a). These differences in the strain-specific immunostimulatory capacities of different LTA molecules are the result of sugar substitutions or replacement of D-alanyl moieties with L-alanyl within the hydrophilic tail (Lebeer et al. 2012).

Exopolysaccharides (EPS) produced and secreted into the extracellular environment by lactic acid-producing bacteria have been studied for their potential immunomodulatory activity. EPS produced by L. acidophilus sp. $5 \mathrm{e} 2$ and $L$. helveticus sp. Rosyjski induce $I L-8$ expression in HT-29-19A IEC (Patten et al. 2014). In contrast, EPS derived from L. plantarum N14 attenuate proinflammatory gene expression in response to treatment with enterotoxigenic Escherichia coli in porcine IEC, an effect mediated through TLR-2, TLR-4, and RP105, a Toll-like receptor protein (Murofushi et al. 2015).

Lactocepins are biologically active proteases that can be either secreted or anchored to bacterial outer cell membrane. They were first identified in Lactococci and have since been identified in Lactobacilli. These proteases have the ability to degrade casein to liberate free amino acids required for growth of lactic acid bacteria during milk fermentation. Recently, a novel role for some lactocepins has been identified: a lactocepin produced by $L$. paracasei selectively degrades the proinflammatory IP-10 chemokine produced by IEC in a chemically induced mouse colitis model. This led to abrogation of cecal tissue inflammation and reduced infiltration of lymphocytes into inflamed tissues (von Schillde et al. 2012; Hormannsperger et al. 2013), suggesting a novel immunomodulatory mechanism of action targeting particular host cytokines.

Peptides and proteins, such as p75 and p40, are cell wall hydrolases with endopeptidase activity, which are responsible for normal separation of L. rhamnosus strain GG cells during replication (Claes et al. 2012). Both p75 and p40 have been reported to reduce cytokineinduced epithelial cell damage in human and mouse colonic epithelial cells (Seth et al. 2008). These proteins activate the Akt cellular pathway to prevent TNF- $\alpha$ induced cell death (Yan et al. 2007), acting through the epidermal growth factor receptor (EGFR) on IEC to induce cytoprotective heat shock proteins (Tao et al. 2006, 2007), reduce apoptosis (Yan et al. 2013) and promote intestinal mucus production (Wang et al. 2014). Recently, p40 has also been shown to up-regulate the production of A proliferation-inducing ligand (APRIL) by IEC and promote IgA production at the mucosal level in mice (Wang et al. 2016).

Bacteria routinely produce $\mathrm{N}$-formyl peptides (fMLF), containing the $\mathrm{N}$-formyl methionine amino acid. fMLF are produced by both pathogenic and commensal bacteria and bind to the formyl peptide receptor (FPR) present on cells of the innate immune system. Once bound, FPR induces pro-inflammatory cytokine and chemokine production and reactive oxygen species (ROS) generation (Migeotte et al. 2006). fMLF produced by L. rhamnosus strain GG up-regulates ROS production in IEC (Wentworth et al. 2011), which, in turn, down-regulates pro-inflammatory cytokine transcription by inhibiting NF- $\kappa \mathrm{B}$ activation, and also promotes intestinal epithelial barrier integrity (Kumar et al. 2007; Lin et al. 2009; Alam et al. 2014).

\section{Immunomodulation by metabolic products and soluble mediators}

Lactic acid is a major metabolite produced during the fermentation of dietary substrates by lactic acidproducing bacteria. Lactic acid suppresses proinflammatory cytokine production, as well as the proliferation and cytotoxic activity of cytotoxic T cells (Fischer et al. 2007), resulting in down-regulation of TLR-4- and TLR-5-induced chemokine expression in IEC. It has also been shown to modulate TLR-induced cytokine production by murine bone marrow-derived macrophages, and down-regulate TLR-induced expression of the co-stimulatory molecule CD40 on bone marrow derived DC (Iraporda et al. 2014, 2015). While lactic acid is well known as a metabolic product of Lactobacilli, its role as a bioactive mediator has received relatively little attention, and only recently has been linked to immunomodulatory activity (Garrote et al. 2015; Pearce and Everts 2015). 
Dietary tryptophan can be metabolized in the gut lumen by Lactobacilli which convert tryptophan into indole and other tryptophan metabolites. Indoles have garnered attention as they are implicated in modulating host immune responses. Bacterially-derived indoles bind to aryl hydrocarbon receptors (AHR) present in immune cells within the GALT (Esser et al. 2009). AHR are intracellular receptors predominantly found within cells lining the skin, lungs, and gastrointestinal tract which are responsible for recognizing and binding small molecular weight endogenous and exogenous molecules such as serotonin and tryptophan metabolites (Hubbard et al. 2015). Once bound, AHR translocate to the nucleus where they act as a transcription factor to upregulate genes involved in xenobiotic metabolism and interact with other signaling pathways, such as the NF- $\kappa$ B signal transduction cascade, suggesting a role for the AHR in inflammation (Vogel et al. 2014). Indoles produced by Lactobacilli induce the production of IL-22 by innate lymphoid cells. The induction of IL-22 is mediated by the binding of indole-3-aldehyde to AHR (Zelante et al. 2013).

Endogenous tryptophan metabolites also activate AHR leading to modulation of pro-inflammatory activity at the cellular level. Tryptophan is primarily metabolised through the kynurenine pathway via the enzyme indoleamine 2,3-dioxygenase (IDO) (Noakes and Mellick 2013). Interestingly, some Lactobacilli strains modulate IDO expression and subsequent tryptophan metabolism in vitro. $\mathrm{H}_{2} \mathrm{O}_{2}$ produced by L. johnsonii significantly inhibits the activity of IDO in HT-29 IEC in vitro (Valladares et al. 2013), reflecting the complexity of tryptophan metabolism in the immunomodulatory activity of certain probiotics and gut microorganisms.

Lactobacilli produce biogenic amines, and histamine production by certain strains has been demonstrated as another immunomodulatory bioactive product of amino acid metabolism in probiotics (Thomas et al. 2012; Hemarajata et al. 2013). Histamine production by L. reuteri 6475 induces elevated cAMP levels in human monocytes, inhibiting MAPK signaling and suppresses TNF- $\alpha$ production. Other novel bioactive molecules produced by probiotics include quorum-sensing molecules (QSM) that allow for interbacterial communication, environmental sampling, stimulation of innate immune responses and activation of gene transcription by both host and bacteria (Hancock et al. 2012). For instance,
QSM derived from the probiotic Bacillus subtilis induce the expression of genes involved in the p38 MAP kinase and Akt survival pathways in IEC (Fujiya et al. 2007). Autoinducer-2 (AI-2), a QSM produced by L. acidophilus NCFM, enhances the adherence capability of the bacterium to Caco-2 human IEC (Buck et al. 2009). Furthermore, a secreted product of $L$. acidophilus La-5 inhibits the expression of virulence factors and production of AI-2 by enterohemorrhagic Escherichia coli O157:H7 (Medellin-Pena et al. 2007).

Overall, current evidence indicates that there is a diverse range of mediators and molecules involved in the interactions between probiotic bacteria and host cells. Such diversity contributes to variation between strains and species of microorganisms and their effects on the immune system. While accumulating evidence indicates that the actions of structural components and soluble mediators on IEC is in keeping with findings regarding microbial communication mechanisms, much remains to be determined about the extent of these effects in vivo and resulting outcomes in the context of immune activity.

\section{Perspectives}

The emerging potential beneficial effects of prebiotics and probiotics are likely to have a wide variety of therapeutic implications in various disease states. Currently, there is growing interest in the use of combination therapy for treating cancer, with much attention on immune regulation and programmed cell death (Zou et al. 2016). Current studies provide promising evidence for the use of probiotics as adjunct therapy to immunotherapy in the setting of cancer. For example, an elegant study employed a murine model of melanoma to show that administration of Bifidobacteria combined with an antibody directed against the programmed cell death (PD)-1 ligand resulted in more effective cancer immunotherapy than either intervention provided alone (Sivan et al. 2015). The effects were mediated by increased numbers of active tumor-specific CD8-positive $\mathrm{T}$ cells in the tumor microenvironment. Since PD-1 checkpoint inhibitor blockade is more effective in the subset of patients with colorectal cancers featuring mutations in DNA mismatch repair genes (Le et al. 2015), probiotic bacteria should now be evaluated as an adjunct to enhance the effectiveness of immune checkpoint blockade, and as precision therapy for these affected individuals. 
The innate and adaptive immune system plays an integral role in preserving a delicate balance between health and disease. Therefore, future studies should provide a more comprehensive understanding of how prebiotics and probiotics, and their metabolic products, can be used as adjunct immunomodulatory therapy to either prevent or manage a wide variety of chronic disease conditions in humans.

\section{Conflict of interests}

Research efforts of the authors are supported by Lallemand Health Solutions (Montreal, Quebec, Canada) and PMS has received honoraria from Abbott Nutrition, Mead Johnson Nutritionals, and Nestlé Nutrition.

\section{Acknowledgements}

Work in the laboratory is funded by research grants from the Canadian Institutes of Health Research (MOP89894, IOP92890). RYW is the recipient of a Vanier Graduate Scholarship Award from the CIHR. PMS is the recipient of a Canada Research Chair in Gastrointestinal Disease.

\section{REFERENCES}

Abrahamsson, T.R., Jakobsson, H.E., Andersson, A.F., Bjorksten, B., Engstrand, L., and Jenmalm, M.C. 2014. Low gut microbiota diversity in early infancy precedes asthma at school age. Clin. Exp. Allergy. 44(6):842-850. PMID: 24330256. doi: 10.1111/cea. 12253.

Alam, A., Leoni, G., Wentworth, C.C., Kwal, J.M., Wu, H., Ardita, C.S., Swanson, P.A., Lambeth, J.D., Jones, R.M., Nusrat, A., and Neish, A.S. 2014. Redox signaling regulates commensal-mediated mucosal homeostasis and restitution and requires formyl peptide receptor 1. Mucosal Immunol. 7(3):645-655. PMID: 24192910. doi: 10.1038/mi.2013.84.

Arpaia, N., Campbell, C., Fan, X., Dikiy, S., van der Veeken, J., deRoos, P., Liu, H., Cross, J.R., Pfeffer, K., Coffer, P.J., and Rudensky, A.Y. 2013. Metabolites produced by commensal bacteria promote peripheral regulatory T-cell generation. Nature. 504(7480):451455. PMID: 24226773. doi: 10.1038/nature12726.

Audy, J., Mathieu, O., Belvis, J., and Tompkins, T.A. 2012. Transcriptomic response of immune signalling pathways in intestinal epithelial cells exposed to lipopolysaccharides, Gram-negative bacteria or potentially probiotic microbes. Benef. Microbes. 3(4):273-286. PMID: 23234729. doi: 10.3920/ BM2012.0027.

Autran, C.A., Schoterman, M.H., Jantscher-Krenn, E., Kamerling, J.P., and Bode, L. 2016. Sialylated galacto-oligosaccharides and 2-fucosyllactose reduce necrotising enterocolitis in neonatal rats. Br. J. Nutr. 116(2):294-299. PMID: 27212112. doi: 10.1017/ S0007114516002038.

Ayres, J.S. 2016. Cooperative microbial tolerance behaviors in host-microbiota mutualism. Cell. 165(6): 1323-1331. PMID: 27259146. doi: 10.1016/j.cell. 2016.05.049.

Bai, A.P., Ouyang, Q., Zhang, W., Wang, C.H., and Li, S.F. 2004. Probiotics inhibit TNF-alpha-induced interleukin-8 secretion of HT29 cells. World J. Gastroenterol. 10(3):455-457. PMID: 14760780.

Baumler, A.J., and Sperandio, V. 2016. Interactions between the microbiota and pathogenic bacteria in the gut. Nature. 535(7610):85-93. PMID: 27383983. doi: $10.1038 /$ nature18849.

Bermudez-Brito, M., Munoz-Quezada, S., GomezLlorente, C., Romero, F., and Gil, A. 2014. Lactobacillus rhamnosus and its cell-free culture supernatant differentially modulate inflammatory biomarkers in Escherichia coli-challenged human dendritic cells. Br. J. Nutr. 111(10):1727-1737. PMID: 24480321. doi: 10.1017/S0007114513004303.

Bode, L., and Jantscher-Krenn, E. 2012. Structurefunction relationships of human milk oligosaccharides. Adv. Nutr. 3(3):383S-391S. PMID: 22585916. doi: 10.3945/an.111.001404.

Braat, H., van den Brande, J., van Tol, E., Hommes, D., Peppelenbosch, M., and van Deventer, S. 2004. Lactobacillus rhamnosus induces peripheral hyporesponsiveness in stimulated CD4+ T cells via modulation of dendritic cell function. Am. J. Clin. Nutr. 80(6):1618-1625.

Buck, B.L., Azcarate-Peril, M.A., and Klaenhammer, T.R. 2009. Role of autoinducer-2 on the adhesion ability of Lactobacillus acidophilus. J. Appl. Microbiol. 107(1):269-279. PMID: 19302300. doi: 10.1111/j. 1365-2672.2009.04204.x.

Candela, M., Perna, F., Carnevali, P., Vitali, B., Ciati, R., Gionchetti, P., Rizzello, F., Campieri, M., and Brigidi, P. 2008. Interaction of probiotic Lactobacillus and Bifidobacterium strains with human intestinal epithelial cells: Adhesion properties, competition against enteropathogens and modulation of IL-8 production. Int. J. Food Microbiol. 125(3):286-292. PMID: 18524406. doi: 10.1016/j.ijfoodmicro.2008.04.012. 
Capitan-Canadas, F., Ortega-Gonzalez, M., Guadix, E., Zarzuelo, A., Suarez, M.D., de Medina, F.S., and Martinez-Augustin, O. 2014. Prebiotic oligosaccharides directly modulate proinflammatory cytokine production in monocytes via activation of TLR4. Mol. Nutr. Food Res. 58(5):1098-1110. PMID: 24549946. doi: 10.1002/mnfr.201300497.

Charbonneau, M.R., O’Donnell, D., Blanton, L.V., Totten, S.M., Davis, J.C., Barratt, M.J., Cheng, J., Guruge, J., Talcott, M., Bain, J.R., Muehlbauer, M.J., Ilkayeva, O., Wu, C., Struckmeyer, T., Barile, D., Mangani, C., Jorgensen, J., Fan, Y.M., Maleta, K., Dewey, K.G., Ashorn, P., Newgard, C.B., Lebrilla, C., Mills, D.A., and Gordon, J.I. 2016. Sialylated milk oligosaccharides promote microbiota-dependent growth in models of infant undernutrition. Cell. 164(5): 859-871. PMID: 26898329. doi: 10.1016/j.cell.2016. 01.024 .

Christoffersen, T.E., Hult, L.T., Kuczkowska, K., Moe, K.M., Skeie, S., Lea, T., and Kleiveland, C.R. 2014. In vitro comparison of the effects of probiotic, commensal and pathogenic strains on macrophage polarization. Probiotics Antimicrob. Proteins. 6(1): 1-10. PMID: 24676762. doi: 10.1007/s12602-0139152-0.

Claes, I.J., Schoofs, G., Regulski, K., Courtin, P., Chapot-Chartier, M.P., Rolain, T., Hols, P., von Ossowski, I., Reunanen, J., de Vos, W.M., Palva, A., Vanderleyden, J., De Keersmaecker, S.C., and Lebeer, S. 2012. Genetic and biochemical characterization of the cell wall hydrolase activity of the major secreted protein of Lactobacillus rhamnosus GG. PLoS ONE. 7(2):e31588. PMID: 22359601. doi: 10.1371/journal. pone.0031588.

Clarke, S.T., Green-Johnson, J.M., Brooks, S.P., Ramdath, D.D., Bercik, P., Avila, C., Inglis, G.D., Green, J., Yanke, L.J., Selinger, L.B., and Kalmokoff, M. 2016. $\beta 2$-1 Fructan supplementation alters host immune responses in a manner consistent with increased exposure to microbial components: Results from a double-blinded, randomised, cross-over study in healthy adults. Br. J. Nutr. 115(10):1748-1759. PMID: 26987626. doi: 10.1017/S0007114516000908.

Correa-Oliveira, R., Fachi, J.L., Vieira, A., Sato, F.T., and Vinolo, M.A. 2016. Regulation of immune cell function by short-chain fatty acids. Clin. Transl. Immunol. 5(4): e73. PMID: 27195116. doi: 10.1038/cti.2016.17.

Coyte, K.Z., Schluter, J., and Foster, K.R. 2015. The ecology of the microbiome: Networks, competition, and stability. Science. 350(6261):663-666. PMID: 26542567. doi: 10.1126/science.aad2602.
David, L.A., Maurice, C.F., Carmody, R.N., Gootenberg, D.B., Button, J.E., Wolfe, B.E., Ling, A.V., Devlin, A.S., Varma, Y., Fischbach, M.A., Biddinger, S.B., Dutton, R.J., and Turnbaugh, P.J. 2014. Diet rapidly and reproducibly alters the human gut microbiome. Nature. 505(7484): 559-563. PMID: 24336217. doi: 10.1038/nature 12820.

Demont, A., Hacini-Rachinel, F., Doucet-Ladeveze, R., Ngom-Bru, C., Mercenier, A., Prioult, G., and Blanchard, C. 2016. Live and heat-treated probiotics differently modulate IL10 mRNA stabilization and microRNA expression. J. Allergy Clin. Immunol. 137(4):1264-7.e1-1264-7.e10. PMID: 26478009. doi: 10.1016/j.jaci.2015.08.033.

Esser, C., Rannug, A., and Stockinger, B. 2009. The aryl hydrocarbon receptor in immunity. Trends Immunol. 30(9):447-454. PMID: 19699679. doi: 10.1016/j. it.2009.06.005.

Eun, C.S., Han, D.S., Lee, S.H., Jeon, Y.C., Sohn, J.H., Kim, Y.S., and Lee, J. 2007. [Probiotics may reduce inflammation by enhancing peroxisome proliferator activated receptor gamma activation in HT-29 cells]. Korean J. Gastroenterol. 49(3):139-146. PMID: 18172341.

Ewaschuk, J., Endersby, R., Thiel, D., Diaz, H., Backer, J., Ma, M., Churchill, T., and Madsen, K. 2007. Probiotic bacteria prevent hepatic damage and maintain colonic barrier function in a mouse model of sepsis. Hepatology. 46(3):841-850. PMID: 17659579. doi: 10.1002/hep.21750.

Faith, J.J., Guruge, J.L., Charbonneau, M., Subramanian, S., Seedorf, H., Goodman, A.L., Clemente, J.C., Knight, R., Heath, A.C., Leibel, R.L., Rosenbaum, M., and Gordon, J.I. 2013. The longterm stability of the human gut microbiota. Science. 341(6141):1237439. PMID: 23828941. doi: 10.1126/ science.1237439.

Falony, G., Joossens, M., Vieira-Silva, S., Wang, J., Darzi, Y., Faust, K., Kurilshikov, A., Bonder, M.J., Valles-Colomer, M., Vandeputte, D., Tito, R.Y., Chaffron, S., Rymenans, L., Verspecht, C., DeSutter, L., Lima-Mendez, G., D'Hoe, K., Jonckheere, K., Homola, D., Garcia, R., Tigchelaar, E.F., Eeckhaudt, L., Fu, J., Henckaerts, L., Zhernakova, A., Wijmenga, C., and Raes, J. 2016. Population-level analysis of gut microbiome variation. Science. 352(6285):560-564. PMID: 27126039. doi: 10.1126/science.aad3503.

Fischbach, M.A., and Segre, J.A. 2016. Signaling in hostassociated microbial communities. Cell. 164(6):12881300. PMID: 26967294. doi: 10.1016/j.cell.2016.02.037. 
Fischer, K., Hoffmann, P., Voelkl, S., Meidenbauer, N., Ammer, J., Edinger, M., Gottfried, E., Schwarz, S., Rothe, G., Hoves, S., Renner, K., Timischl, B., Mackensen, A., Kunz-Schughart, L., Andreesen, R., Krause, S.W., and Kreutz, M. 2007. Inhibitory effect of tumor cell-derived lactic acid on human T cells. Blood. 109(9):3812-3819. PMID: 17255361. doi: 10.1182/blood-2006-07-035972.

Fong, F.L., Kirjavainen, P.V., and El-Nezami, H. 2016. Immunomodulation of Lactobacillus rhamnosus GG (LGG)-derived soluble factors on antigen-presenting cells of healthy blood donors. Sci. Rep. 6:22845. PMID: 26961406. doi: 10.1038/srep22845.

Freedman, S.B., Williamson-Urquhart, S., Schuh, S., Sherman, P.M., Farion, K.J., Gouin, S., Willan, A.R., Goeree, R., Johnson, D.W., Black, K., Schnadower, D., Gorelick, M.H., and Pediatric Emergency Research Canada Gastroenteritis Study Group. 2014. Impact of emergency department probiotic treatment of pediatric gastroenteritis: Study protocol for the PROGUT (Probiotic Regimen for Outpatient Gastroenteritis Utility of Treatment) randomized controlled trial. Trials. 15:170. PMID: 24885220. doi: 10.1186/17456215-15-170.

Fujiya, M., Musch, M.W., Nakagawa, Y., Hu, S., Alverdy, J., Kohgo, Y., Schneewind, O., Jabri, B., and Chang, E.B. 2007. The Bacillus subtilis quorumsensing molecule CSF contributes to intestinal homeostasis via OCTN2, a host cell membrane transporter. Cell Host Microbe. 1(4):299-308. PMID: 18005709. doi: 10.1016/j.chom.2007.05.004.

Fusunyan, R.D., Quinn, J.J., Fujimoto, M., MacDermott, R.P., and Sanderson, I.R. 1999. Butyrate switches the pattern of chemokine secretion by intestinal epithelial cells through histone acetylation. Mol. Med. 5(9):631-640. PMID: 10551904.

Ganguli, K., Meng, D., Rautava, S., Lu, L., Walker, W.A., and Nanthakumar, N. 2013. Probiotics prevent necrotizing enterocolitis by modulating enterocyte genes that regulate innate immune-mediated inflammation. Am. J. Physiol. Gastrointest. Liver Physiol. 304(2):G132-G141. PMID: 23139215. doi: 10.1152/ ajpgi.00142.2012.

Gareau, M.G., Wine, E., Reardon, C., and Sherman, P.M. 2010. Probiotics prevent death caused by Citrobacter rodentium infection in neonatal mice. J. Infect. Dis. 201(1):81-91. PMID: 19961304. doi: 10.1086/648614.

Garrote, G.L., Abraham, A.G., and Rumbo, M. 2015. Is lactate an undervalued functional component of fermented food products? Front. Microbiol. 6:629. PMID: 26150815. doi: 10.3389/fmicb.2015.00629.
Geijtenbeek, T.B., and Gringhuis, S.I. 2009. Signalling through C-type lectin receptors: Shaping immune responses. Nat. Rev. Immunol. 9(7):465-479. PMID: 19521399. doi: 10.1038/nri2569.

Ghadimi, D., Helwig, U., Schrezenmeir, J., Heller, K.J., and de Vrese, M. 2012. Epigenetic imprinting by commensal probiotics inhibits the IL-23/IL-17 axis in an in vitro model of the intestinal mucosal immune system. J. Leukoc. Biol. 92(4):895-911. PMID: 22730546. doi: 10.1189/jlb.0611286.

Giahi, L., Aumueller, E., Elmadfa, I., and Haslberger, A.G. 2012. Regulation of TLR4, p38 MAPkinase, IKB and miRNAs by inactivated strains of lactobacilli in human dendritic cells. Benef. Microbes. 3(2):91-98. PMID: 22476320. doi: 10.3920/BM2011.0052.

Gilbert, J.A., Quinn, R.A., Debelius, J., Xu, Z.Z., Morton, J., Garg, N., Jansson, J.K., Dorrestein, P.C., and Knight, R. 2016. Microbiome-wide association studies link dynamic microbial consortia to disease. Nature. 535(7610):94-103. PMID: 27383984. doi: 10.1038 /nature 18850 .

Ginsburg, I. 2002. Role of lipoteichoic acid in infection and inflammation. Lancet Infect. Dis. 2(3):171-179. PMID: 11944187. doi: 10.1016/S1473-3099(02) 00226-8.

Habil, N., Al-Murrani, W., Beal, J., and Foey, A.D. 2011. Probiotic bacterial strains differentially modulate macrophage cytokine production in a strain-dependent and cell subset-specific manner. Benef. Microbes. 2(4):283-293. PMID: 22146688. doi: 10.3920/BM2011.0027.

Hallam, M.C., and Reimer, R.A. 2014. Postnatal prebiotic fiber intake in offspring exposed to gestational protein restriction has sex-specific effects on insulin resistance and intestinal permeability in rats. J. Nutr. 144(10):1556-1563. PMID: 25080539. doi: 10.3945/jn.114.194142.

Hancock, R.E., Nijnik, A., and Philpott, D.J. 2012. Modulating immunity as a therapy for bacterial infections. Nat. Rev. Microbiol. 10(4):243-254. PMID: 22421877. doi: 10.1038/nrmicro2745.

Harb, H., van Tol, E.A., Heine, H., Braaksma, M., Gross, G., Overkamp, K., Hennen, M., Alrifai, M., Conrad, M.L., Renz, H., and Garn, H. 2013. Neonatal supplementation of processed supernatant from Lactobacillus rhamnosus GG improves allergic airway inflammation in mice later in life. Clin. Exp. Allergy. 43(3):353-364. PMID: 23414544. doi: 10.1111/cea.12047.

Hardy, H., Harris, J., Lyon, E., Beal, J., and Foey, A.D. 2013. Probiotics, prebiotics and immunomodulation 
of gut mucosal defences: Homeostasis and immunopathology. Nutrients. 5(6):1869-1912. PMID: 23760057. doi: 10.3390/nu5061869.

Hayes, C.L., Natividad, J.M., Jury, J., Martin, R., Langella, P., and Verdu, E.F. 2014. Efficacy of Bifidobacterium breve NCC2950 against DSS-induced colitis is dependent on bacterial preparation and timing of administration. Benef. Microbes. 5(1):79-88. PMID: 24533977. doi: 10.3920/BM2013.0039.

He, C., Shan, Y., and Song, W. 2015. Targeting gut microbiota as a possible therapy for diabetes. Nutr. Res. 35(5):361-367. PMID: 25818484. doi: 10.1016/j. nutres.2015.03.002.

Hemarajata, P., and Versalovic, J. 2013. Effects of probiotics on gut microbiota: Mechanisms of intestinal immunomodulation and neuromodulation. Therap. Adv. Gastroenterol. 6(1):39-51. PMID: 23320049. doi: 10.1177/1756283X12459294.

Hemarajata, P., Gao, C., Pflughoeft, K.J., Thomas, C.M., Saulnier, D.M., Spinler, J.K., and Versalovic, J. 2013. Lactobacillus reuteri-specific immunoregulatory gene rsiR modulates histamine production and immunomodulation by Lactobacillus reuteri. J. Bacteriol. 195(24):5567-5576. PMID: 24123819. doi: 10.1128/ JB.00261-13.

Hill, C., Guarner, F., Reid, G., Gibson, G.R., Merenstein, D.J., Pot, B., Morelli, L., Canani, R.B., Flint, H.J., Salminen, S., Calder, P.C., and Sanders, M.E. 2014. Expert consensus document. The International Scientific Association for Probiotics and Prebiotics consensus statement on the scope and appropriate use of the term probiotic. Nat. Rev. Gastroenterol. Hepatol. 11(8):506-514. PMID: 24912386. doi: 10.1038/nrgastro.2014.66.

Ho, N.K., Hawley, S.P., Ossa, J.C., Mathieu, O., Tompkins, T.A., Johnson-Henry, K.C., and Sherman, P.M. 2013. Immune signalling responses in intestinal epithelial cells exposed to pathogenic Escherichia coli and lactic acid-producing probiotics. Benef. Microbes. 4(2):195-209. PMID: 23443951. doi: 10.3920/BM2012.0038.

Honda, K., and Littman, D.R. 2016. The microbiota in adaptive immune homeostasis and disease. Nature. 535(7610):75-84. PMID: 27383982. doi: 10.1038/ nature18848.

Hormannsperger, G., von Schillde, M.A., and Haller, D. 2013. Lactocepin as a protective microbial structure in the context of IBD. Gut Microbes. 4(2):152-157. PMID: 23333860. doi: 10.4161/gmic.23444.

Hubbard, T.D., Murray, I.A., Bisson, W.H., Lahoti, T.S., Gowda, K., Amin, S.G., Patterson, A.D., and
Perdew, G.H. 2015. Adaptation of the human aryl hydrocarbon receptor to sense microbiota-derived indoles. Sci. Rep. 5:12689. PMID: 26235394. doi: $10.1038 /$ srep 12689 .

Imaoka, A., and Umesaki, Y. 2009. Rationale for using of Bifidobacterium probiotic strains-fermented milk against colitis based on animal experiments and clinical trials. Probiotics Antimicrob. Proteins. 1(1):8-14. PMID: 26783127. doi: 10.1007/s12602-008-9001-8.

Iraporda, C., Errea, A., Romanin, D.E., Cayet, D., Pereyra, E., Pignataro, O., Sirard, J.C., Garrote, G.L., Abraham, A.G., and Rumbo, M. 2015. Lactate and short chain fatty acids produced by microbial fermentation downregulate proinflammatory responses in intestinal epithelial cells and myeloid cells. Immunobiology. 220(10):1161-1169. PMID: 26101138. doi: 10.1016/j.imbio.2015.06.004.

Iraporda, C., Romanin, D.E., Rumbo, M., Garrote, G.L., and Abrahama, A.G. 2014. The role of lactate on the immunomodulatory properties of the nonbacterial fraction of kefir. Food Res. Int. 62:247-253. doi: 10.1016/j.foodres.2014.03.003.

Isidro, R.A., Bonilla, F.J., Pagan, H., Cruz, M.L., Lopez, P., Godoy, L., Hernandez, S., Loucil-Alicea, R.Y., RiveraAmill, V., Yamamura, Y., Isidro, A.A., and Appleyard, C.B. 2014. The probiotic mixture VSL\#3 alters the morphology and secretion profile of both polarized and unpolarized human macrophages in a polarization-dependent manner. J. Clin. Cell. Immunol. 5(3):1000227. PMID: 25177525. doi: 10.4172/21559899.1000227.

Iyer, C., Kosters, A., Sethi, G., Kunnumakkara, A.B., Aggarwal, B.B., and Versalovic, J. 2008. Probiotic Lactobacillus reuteri promotes TNF-induced apoptosis in human myeloid leukemia-derived cells by modulation of NF-kappaB and MAPK signaling. Cell. Microbiol. 10(7):1442-1452. PMID: 18331465. doi: 10.1111/j.1462-5822.2008.01137.x.

Johnson-Henry, K.C., Abrahamsson, T.R., Wu, R.Y., and Sherman, P.M. 2016. Probiotics, prebiotics, and synbiotics for the prevention of necrotizing enterocolitis. Adv. Nutr. 7(5):928-937. PMID: 27633108. doi: 10.3945/an.116.012237.

Johnson-Henry, K.C., Nadjafi, M., Avitzur, Y., Mitchell, D.J., Ngan, B.Y., Galindo-Mata, E., Jones, N.L., and Sherman, P.M. 2005. Amelioration of the effects of Citrobacter rodentium infection in mice by pretreatment with probiotics. J. Infect. Dis. 191(12): 2106-2117. PMID: 15897997. doi: 10.1086/430318.

Johnson-Henry, K.C., Pinnell, L.J., Waskow, A.M., Irrazabal, T., Martin, A., Hausner, M., and 
Sherman, P.M. 2014. Short-chain fructooligosaccharide and inulin modulate inflammatory responses and microbial communities in Caco2bbe cells and in a mouse model of intestinal injury. J. Nutr. 144(11):1725-1733. PMID: 25143376. doi: $10.3945 /$ jn.114.195081.

Kabat, A.M., Srinivasan, N., and Maloy, K.J. 2014. Modulation of immune development and function by intestinal microbiota. Trends Immunol. 35(11):507-517. PMID: 25172617. doi: 10.1016/j. it.2014.07.010.

Kim, H., Jung, B.J., Jung, J.H., Kim, J.Y., Chung, S.K., and Chung, D.K. 2012. Lactobacillus plantarum lipoteichoic acid alleviates TNF- $\alpha$-induced inflammation in the HT-29 intestinal epithelial cell line. Mol. Cells. 33(5):479-486. PMID: 22526394. doi: 10.1007/ s10059-012-2266-5.

Kim, H.G., Lee, S.Y., Kim, N.R., Ko, M.Y., Lee, J.M., Yi, T.H., Chung, S.K., and Chung, D.K. 2008. Inhibitory effects of Lactobacillus plantarum lipoteichoic acid (LTA) on Staphylococcus aureus LTA-induced tumor necrosis factor-alpha production. J. Microbiol. Biotechnol. 18(6):1191-1196. PMID: 18600067.

Kim, J.Y., Kim, H., Jung, B.J., Kim, N.R., Park, J.E., and Chung, D.K. 2013a. Lipoteichoic acid isolated from Lactobacillus plantarum suppresses LPS-mediated atherosclerotic plaque inflammation. Mol. Cells. 35(2):115-124. PMID: 23456333. doi: 10.1007/s10059013-2190-3.

Kim, M., Qie, Y., Park, J., and Kim, C.H. 2016. Gut microbial metabolites fuel host antibody responses. Cell Host Microbe. 20(2):202-214. PMID: 27476413. doi: 10.1016/j.chom.2016.07.001.

Kim, M.H., Kang, S.G., Park, J.H., Yanagisawa, M., and Kim, C.H. 2013b. Short-chain fatty acids activate GPR41 and GPR43 on intestinal epithelial cells to promote inflammatory responses in mice. Gastroenterology. 145(2):396-406.e10. doi: 10.1053/ j.gastro.2013.04.056.

Kim, S.O., Sheikh, H.I., Ha, S.D., Martins, A., and Reid, G. 2006. G-CSF-mediated inhibition of JNK is a key mechanism for Lactobacillus rhamnosus-induced suppression of TNF production in macrophages. Cell. Microbiol. 8(12):1958-1971. PMID: 16889627. doi: 10.1111/j.1462-5822. 2006.00763.x.

Ko, J.S., Yang, H.R., Chang, J.Y., and Seo, J.K. 2007. Lactobacillus plantarum inhibits epithelial barrier dysfunction and interleukin- 8 secretion induced by tumor necrosis factor-alpha. World J. Gastroenterol.
13(13):1962-1965. PMID: 17461497. doi: 10.3748/ wjg.v13.i13.1962.

Konieczna, P., Groeger, D., Ziegler, M., Frei, R., Ferstl, R., Shanahan, F., Quigley, E.M., Kiely, B., Akdis, C.A., and O’Mahony, L. 2012. Bifidobacterium infantis 35624 administration induces Foxp3 T regulatory cells in human peripheral blood: Potential role for myeloid and plasmacytoid dendritic cells. Gut. 61(3):354-366. PMID: 22052061. doi: 10.1136/gutjnl-2011-300936.

Konieczna, P., Schiavi, E., Ziegler, M., Groeger, D., Healy, S., Grant, R., and O'Mahony, L. 2015. Human dendritic cell DC-SIGN and TLR-2 mediate complementary immune regulatory activities in response to Lactobacillus rhamnosus JB-1. PLoS ONE. 10(3): e0120261. PMID: 25816321. doi: 10.1371/journal. pone.0120261.

Konstantinov, S.R., Smidt, H., de Vos, W.M., Bruijns, S.C., Singh, S.K., Valence, F., Molle, D., Lortal, S., Altermann, E., Klaenhammer, T.R., and van Kooyk, Y. 2008. S layer protein A of Lactobacillus acidophilus NCFM regulates immature dendritic cell and T cell functions. Proc. Natl. Acad. Sci. USA. 105(49): 19474-19479. PMID: 19047644. doi: 10.1073/pnas. 0810305105.

Kovacs-Nolan, J., Kanatani, H., Nakamura, A., Ibuki, M., and Mine, Y. 2013. $\beta$-1,4-mannobiose stimulates innate immune responses and induces TLR4dependent activation of mouse macrophages but reduces severity of inflammation during endotoxemia in mice. J. Nutr. 143(3):384-391. PMID: 23343679. doi: 10.3945/jn.112.167866.

Kristensen, N.B., Bryrup, T., Allin, K.H., Nielsen, T., Hansen, T.H., and Pedersen, O. 2016. Alterations in fecal microbiota composition by probiotic supplementation in healthy adults: A systematic review of randomized controlled trials. Genome Med. 8(1):52. PMID: 27159972. doi: 10.1186/s13073-016-0300-5.

Kumar, A., Wu, H., Collier-Hyams, L.S., Hansen, J.M., Li, T., Yamoah, K., Pan, Z.Q., Jones, D.P., and Neish, A.S. 2007. Commensal bacteria modulate cullin-dependent signaling via generation of reactive oxygen species. EMBO J. 26(21):4457-4466. PMID: 17914462. doi: 10.1038/sj.emboj.7601867.

Latham, T., Mackay, L., Sproul, D., Karim, M., Culley, J., Harrison, D.J., Hayward, L., LangridgeSmith, P., Gilbert, N., and Ramsahoye, B.H. 2012. Lactate, a product of glycolytic metabolism, inhibits histone deacetylase activity and promotes changes in gene expression. Nucleic Acids Res. 40(11): 4794-4803. PMID: 22323521. doi: 10.1093/nar/ gks066. 
Lathrop, S.K., Bloom, S.M., Rao, S.M., Nutsch, K., Lio, C.W., Santacruz, N., Peterson, D.A., Stappenbeck, T.S., and Hsieh, C.S. 2011. Peripheral education of the immune system by colonic commensal microbiota. Nature. 478(7368):250-254. PMID: 21937990. doi: 10.1038 /nature10434.

Le, D.T., Uram, J.N., Wang, H., Bartlett, B.R., Kemberling, H., Eyring, A.D., Skora, A.D., Luber, B.S., Azad, N.S., Laheru, D., Biedrzycki, B., Donehower, R.C., Zaheer, A., Fisher, G.A., Crocenzi, T.S., Lee, J.J., Duffy, S.M., Goldberg, R.M., delaChapelle, A., Koshiji, M., Bhaijee, F., Huebner, T., Hruban, R.H., Wood, L.D., Cuka, N., Pardoll, D.M., Papadopoulos, N., Kinzler, K.W., Zhou, S., Cornish, T.C., Taube, J.M., Anders, R.A., Eshleman, J.R., Vogelstein, B., and Diaz, L.A., Jr. 2015. PD-1 blockade in tumors with mismatch-repair deficiency. N. Engl. J. Med. 372(26):2509-2520. PMID: 26028255. doi: 10.1056/NEJMoa1500596.

Lebeer, S., Claes, I.J., and Vanderleyden, J. 2012. Antiinflammatory potential of probiotics: Lipoteichoic acid makes a difference. Trends Microbiol. 20(1): 5-10. PMID: 22030243. doi: 10.1016/j.tim.2011. 09.004 .

Lebeer, S., Vanderleyden, J., and De Keersmaecker, S.C. 2010. Host interactions of probiotic bacterial surface molecules: Comparison with commensals and pathogens. Nat. Rev. Microbiol. 8(3):171-184. PMID: 20157338. doi: 10.1038/nrmicro2297.

Lehmann, S., Hiller, J., van Bergenhenegouwen, J., Knippels, L.M., Garssen, J., and Traidl-Hoffmann, C. 2015. In vitro evidence for immune-modulatory properties of non-digestible oligosaccharides: Direct effect on human monocyte derived dendritic cells. PLoS ONE. 10(7):e0132304. PMID: 26148091. doi: 10.1371/journal.pone.0132304.

Lin, P.W., Myers, L.E., Ray, L., Song, S.C., Nasr, T.R., Berardinelli, A.J., Kundu, K., Murthy, N., Hansen, J.M., and Neish, A.S. 2009. Lactobacillus rhamnosus blocks inflammatory signaling in vivo via reactive oxygen species generation. Free Radic. Biol. Med. 47(8):1205-1211. PMID: 19660542. doi: 10.1016/j. freeradbiomed.2009.07.033.

Lin, Q., Mathieu, O., Tompkins, T.A., Buckley, N.D., and Green-Johnson, J.M. 2016. Modulation of the $\mathrm{TNF} \alpha$-induced gene expression profile of intestinal epithelial cells by soy fermented with lactic acid bacteria. J. Funct. Foods. 23:400-411. doi: 10.1016/j. jff.2016.02.047.

Liu, S., da Cunha, A.P., Rezende, R.M., Cialic, R., Wei, Z., Bry, L., Comstock, L.E., Gandhi, R., and Weiner, H.L.
2016. The host shapes the gut microbiota via fecal microRNA. Cell Host Microbe. 19(1):32-43. PMID: 26764595. doi: 10.1016/j.chom.2015.12.005.

Lomax, A.R., Cheung, L.V., Noakes, P.S., Miles, E.A., and Calder, P.C. 2015. Inulin-type $\beta 2-1$ fructans have some effect on the antibody response to seasonal influenza vaccination in healthy middle-aged humans. Front. Immunol. 6:490. PMID: 26441994. doi: 10.3389/fimmu.2015.00490.

Lomax, A.R., Cheung, L.V., Tuohy, K.M., Noakes, P.S., Miles, E.A., and Calder, P.C. 2012. $\beta 2-1$ Fructans have a bifidogenic effect in healthy middle-aged human subjects but do not alter immune responses examined in the absence of an in vivo immune challenge: Results from a randomised controlled trial. Br. J. Nutr. 108(10):1818-1828. PMID: 22244014. doi: $10.1017 /$ S0007114511007276.

Ma, D., Forsythe, P., and Bienenstock, J. 2004. Live Lactobacillus rhamnosus [corrected] is essential for the inhibitory effect on tumor necrosis factor alphainduced interleukin-8 expression. Infect. Immun. 72(9):5308-5314. PMID: 15322027. doi: 10.1128/ IAI.72.9.5308-5314.2004.

Macpherson, C., Audy, J., Mathieu, O., and Tompkins, T.A. 2014. Multistrain probiotic modulation of intestinal epithelial cells' immune response to a double-stranded RNA ligand, poly $(\mathrm{i} \cdot \mathrm{c})$. Appl. Environ. Microbiol. 80(5):1692-1700. PMID: 24375132. doi: 10.1128/AEM.03411-13.

Marchesi, J.R., Adams, D.H., Fava, F., Hermes, G.D., Hirschfield, G.M., Hold, G., Quraishi, M.N., Kinross, J., Smidt, H., Tuohy, K.M., Thomas, L.V., Zoetendal, E.G., and Hart, A. 2016. The gut microbiota and host health: A new clinical frontier. Gut. 65(2):330-339. PMID: 26338727. doi: 10.1136/ gutjnl-2015-309990.

Martinez, F.O., and Gordon, S. 2014. The M1 and M2 paradigm of macrophage activation: Time for reassessment. F1000Prime Rep. 6:13. PMID: 24669294. doi: 10.12703/P6-13.

Martinez-Nunez, R.T., Louafi, F., Friedmann, P.S., and Sanchez-Elsner, T. 2009. MicroRNA-155 modulates the pathogen binding ability of dendritic cells (DCs) by down-regulation of DC-specific intercellular adhesion molecule-3 grabbing non-integrin (DC-SIGN). J. Biol. Chem. 284(24):16334-16342. PMID: 19386588. doi: 10.1074/jbc.M109.011601.

Maslowski, K.M., Vieira, A.T., Ng, A., Kranich, J., Sierro, F., Yu, D., Schilter, H.C., Rolph, M.S., Mackay, F., Artis, D., Xavier, R.J., Teixeira, M.M., and Mackay, C.R. 2009. Regulation of inflammatory 
responses by gut microbiota and chemoattractant receptor GPR43. Nature. 461(7268):1282-1286. PMID: 19865172. doi: 10.1038/nature08530.

McCracken, V.J., Chun, T., Baldeon, M.E., Ahrne, S., Molin, G., Mackie, R.I., and Gaskins, H.R. 2002. TNF-alpha sensitizes HT-29 colonic epithelial cells to intestinal lactobacilli. Exp. Biol. Med. (Maywood). 227(8):665-670. PMID: 12192111.

Mechoud, M.A., Mateos, M.V., de Valdez, G.F., Villena, J., Salvador, G.A., and Rodriguez, A.V. 2012. Lactobacillus reuteri CRL1098 soluble factors modulate tumor necrosis factor alpha production in peripheral blood mononuclear cells: Involvement of lipid rafts. Int. Immunopharmacol. 14(4):446-453. PMID: 22982041. doi: 10.1016/j.intimp.2012.08.020.

Medellin-Pena, M.J., Wang, H., Johnson, R., Anand, S., and Griffiths, M.W. 2007. Probiotics affect virulencerelated gene expression in Escherichia coli O157:H7. Appl. Environ. Microbiol. 73(13):4259-4267. PMID: 17496132. doi: 10.1128/AEM.00159-07.

Menard, S., Candalh, C., Bambou, J.C., Terpend, K., Cerf-Bensussan, N., and Heyman, M. 2004. Lactic acid bacteria secrete metabolites retaining antiinflammatory properties after intestinal transport. Gut. 53(6):821-828. PMID: 15138208. doi: 10.1136/ gut.2003.026252.

Miettinen, M., Lehtonen, A., Julkunen, I., and Matikainen, S. 2000. Lactobacilli and Streptococci activate NF-kappa B and STAT signaling pathways in human macrophages. J. Immunol. 164(7):3733-3740. PMID: 10725732. doi: 10.4049/jimmunol.164.7.3733.

Migeotte, I., Communi, D., and Parmentier, M. 2006. Formyl peptide receptors: A promiscuous subfamily of $G$ protein-coupled receptors controlling immune responses. Cytokine Growth Factor Rev. 17(6): 501-519. PMID: 17084101. doi: 10.1016/j.cytogfr.2006. 09.009 .

Monaco, C.L., Gootenberg, D.B., Zhao, G., Handley, S.A., Ghebremichael, M.S., Lim, E.S., Lankowski, A., Baldridge, M.T., Wilen, C.B., Flagg, M., Norman, J.M., Keller, B.C., Luevano, J.M., Wang, D., Boum, Y., Martin, J.N., Hunt, P.W., Bangsberg, D.R., Siedner, M.J., Kwon, D.S., and Virgin, H.W. 2016. Altered virome and bacterial microbiome in human immunodeficiency virus-associated acquired immunodeficiency syndrome. Cell Host Microbe. 19(3):311-322. PMID: 26962942. doi: 10.1016/j. chom.2016.02.011.

Murata, K., Tomosada, Y., Villena, J., Chiba, E., Shimazu, T., Aso, H., Iwabuchi, N., Xiao, J.Z., Saito, T., and Kitazawa, H. 2014. Bifidobacterium breve MCC-117 induces tolerance in porcine intestinal epithelial cells: Study of the mechanisms involved in the immunoregulatory effect. Biosci. Microbiota Food Health. 33(1):1-10. PMID: 24936377. doi: 10.12938/bmfh.33.1.

Murofushi, Y., Villena, J., Morie, K., Kanmani, P., Tohno, M., Shimazu, T., Aso, H., Suda, Y., Hashiguchi, K., Saito, T., and Kitazawa, H. 2015. The toll-like receptor family protein RP105/MD1 complex is involved in the immunoregulatory effect of exopolysaccharides from Lactobacillus plantarum N14. Mol. Immunol. 64(1):63-75. PMID: 25466614. doi: 10.1016/j.molimm.2014.10.027.

Musilova, S., Rada, V., Vlkova, E., and Bunesova, V. 2014. Beneficial effects of human milk oligosaccharides on gut microbiota. Benef. Microbes. 5(3): 273-283. PMID: 24913838. doi: 10.3920/BM2013. 0080 .

Nandakumar, N.S., Pugazhendhi, S., Madhu Mohan, K., Jayakanthan, K., and Ramakrishna, B.S. 2009. Effect of Vibrio cholerae on chemokine gene expression in HT29 cells and its modulation by Lactobacillus GG. Scand. J. Immunol. 69(3):181-187. PMID: 19281529. doi: 10.1111/j.1365-3083.2008.02214.x.

Neish, A.S., Gewirtz, A.T., Zeng, H., Young, A.N., Hobert, M.E., Karmali, V., Rao, A.S., and Madara, J.L. 2000. Prokaryotic regulation of epithelial responses by inhibition of IkappaB-alpha ubiquitination. Science. 289(5484):1560-1563. PMID: 10968793. doi: 10.1126/ science.289.5484.1560.

Noakes, R., and Mellick, N. 2013. Immunohistochemical studies of the kynurenine pathway in morphea. Int. J. Tryptophan Res. 6:97-102. PMID: 24385714. doi: 10.4137/IJTR.S13371.

O'Callaghan, J., Butto, L.F., MacSharry, J., Nally, K., and O'Toole, P.W. 2012. Influence of adhesion and bacteriocin production by Lactobacillus salivarius on the intestinal epithelial cell transcriptional response. Appl. Environ. Microbiol. 78(15):5196-5203. PMID: 22610429. doi: 10.1128/AEM.00507-12.

O'Flaherty, S., and Klaenhammer, T.R. 2012. Influence of exposure time on gene expression by human intestinal epithelial cells exposed to Lactobacillus acidophilus. Appl. Environ. Microbiol. 78(14): 5028-5032. PMID: 22562992. doi: 10.1128/AEM. 00504-12.

O’Hara, A.M., O’Regan, P., Fanning, A., O’Mahony, C., Macsharry, J., Lyons, A., Bienenstock, J., OMahony, L., and Shanahan, F. 2006. Functional modulation of human intestinal epithelial cell responses by Bifidobacterium infantis and Lactobacillus salivarius. 
Immunology. 118(2):202-215. PMID: 16771855. doi: 10.1111/j.1365-2567.2006.02358.x.

O’Mahony, L., O'Callaghan, L., McCarthy, J., Shilling, D., Scully, P., Sibartie, S., Kavanagh, E., Kirwan, W.O., Redmond, H.P., Collins, J.K., and Shanahan, F. 2006. Differential cytokine response from dendritic cells to commensal and pathogenic bacteria in different lymphoid compartments in humans. Am. J. Physiol. Gastrointest. Liver Physiol. 290(4):G839-G845. PMID: 16293657. doi: 10.1152/ ajpgi.00112.2005.

Ortega-Gonzalez, M., Ocon, B., Romero-Calvo, I., Anzola, A., Guadix, E., Zarzuelo, A., Suarez, M.D., Sanchez de Medina, F., and Martinez-Augustin, O. 2014. Nondigestible oligosaccharides exert nonprebiotic effects on intestinal epithelial cells enhancing the immune response via activation of TLR4-NFKB. Mol. Nutr. Food Res. 58(2):384-393. PMID: 24039030. doi: 10.1002/mnfr.201300296.

Patten, D.A., Leivers, S., Chadha, M.J., Maqsood, M., Humphreys, P.N., Laws, A.P., and Collett, A. 2014. The structure and immunomodulatory activity on intestinal epithelial cells of the EPSs isolated from Lactobacillus helveticus sp. Rosyjski and Lactobacillus acidophilus sp. 5e2. Carbohydr. Res. 384:119-127. PMID: 24394883. doi: 10.1016/j. carres.2013.12.008.

Pearce, E.J., and Everts, B. 2015. Dendritic cell metabolism. Nat. Rev. Immunol. 15(1):18-29. PMID: 25534620. doi: 10.1038/nri3771.

Petersen, C., and Round, J.L. 2014. Defining dysbiosis and its influence on host immunity and disease. Cell. Microbiol. 16(7):1024-1033. PMID: 24798552. doi: 10.1111/cmi.12308.

Peterson, L.W., and Artis, D. 2014. Intestinal epithelial cells: Regulators of barrier function and immune homeostasis. Nat. Rev. Immunol. 14(3):141-153. PMID: 24566914. doi: 10.1038/nri3608.

Rachmilewitz, D., Katakura, K., Karmeli, F., Hayashi, T., Reinus, C., Rudensky, B., Akira, S., Takeda, K., Lee, J., Takabayashi, K., and Raz, E. 2004. Toll-like receptor 9 signaling mediates the anti-inflammatory effects of probiotics in murine experimental colitis. Gastroenterology. 126(2):520-528. PMID: 14762789. doi: 10.1053/j.gastro.2003.11.019.

Riedel, C.U., Foata, F., Philippe, D., Adolfsson, O., Eikmanns, B.J., and Blum, S. 2006. Anti-inflammatory effects of bifidobacteria by inhibition of LPS-induced NF-kappaB activation. World J. Gastroenterol. 12(23):3729-3735. PMID: 16773690. doi: 10.3748/ wjg.v12.i23.3729.
Roberfroid, M. 2007. Prebiotics: The concept revisited. J. Nutr. 137(3 Suppl 2):830S-837S. PMID: 17311983.

Rolig, A.S., Parthasarathy, R., Burns, A.R., Bohannan, B.J., and Guillemin, K. 2015. Individual members of the microbiota disproportionately modulate host innate immune responses. Cell Host Microbe. 18(5): 613-620. PMID: 26567512. doi: 10.1016/j.chom.2015. 10.009.

Ruiz, L., Hevia, A., Bernardo, D., Margolles, A., and Sanchez, B. 2014. Extracellular molecular effectors mediating probiotic attributes. FEMS Microbiol. Lett. 359(1):1-11. PMID: 25115731. doi: 10.1111/15746968.12576.

Sanders, M.E., Guarner, F., Guerrant, R., Holt, P.R., Quigley, E.M., Sartor, R.B., Sherman, P.M., and Mayer, E.A. 2013. An update on the use and investigation of probiotics in health and disease. Gut. 62(5):787-796. PMID: 23474420. doi: 10.1136/gutjnl2012-302504.

Schroder, N.W., Morath, S., Alexander, C., Hamann, L., Hartung, T., Zahringer, U., Gobel, U.B., Weber, J.R., and Schumann, R.R. 2003. Lipoteichoic acid (LTA) of Streptococcus pneumoniae and Staphylococcus aureus activates immune cells via Toll-like receptor (TLR)-2, lipopolysaccharide-binding protein (LBP), and CD14, whereas TLR-4 and MD-2 are not involved. J. Biol. Chem. 278(18):15587-15594. PMID: 12594207. doi: 10.1074/jbc.M212829200.

Seth, A., Yan, F., Polk, D.B., and Rao, R.K. 2008. Probiotics ameliorate the hydrogen peroxide-induced epithelial barrier disruption by a PKC- and MAP kinase-dependent mechanism. Am. J. Physiol. Gastrointest. Liver Physiol. 294(4):G1060-G1069. PMID: 18292183. doi: 10.1152/ajpgi.00202.2007.

Shastri, P., McCarville, J., Kalmokoff, M., Brooks, S.P., and Green-Johnson, J.M. 2015. Sex differences in gut fermentation and immune parameters in rats fed an oligofructose-supplemented diet. Biol. Sex Differ. 6:13. PMID: 26251695. doi: 10.1186/s13293-0150031-0.

Sivan, A., Corrales, L., Hubert, N., Williams, J.B., Aquino-Michaels, K., Earley, Z.M., Benyamin, F.W., Lei, Y.M., Jabri, B., Alegre, M.L., Chang, E.B., and Gajewski, T.F. 2015. Commensal Bifidobacterium promotes antitumor immunity and facilitates antiPD-L1 efficacy. Science. 350(6264):1084-1089. PMID: 26541606. doi: 10.1126/science.aac4255.

Smith, P.M., Howitt, M.R., Panikov, N., Michaud, M., Gallini, C.A., Bohlooly, Y.M., Glickman, J.N., and Garrett, W.S. 2013. The microbial metabolites, short-chain fatty acids, regulate colonic Treg cell 
homeostasis. Science. 341(6145):569-573. PMID: 23828891. doi: 10.1126/science.1241165.

Smits, H.H., Engering, A., van der Kleij, D., de Jong, E.C., Schipper, K., van Capel, T.M., Zaat, B.A., Yazdanbakhsh, M., Wierenga, E.A., van Kooyk, Y., and Kapsenberg, M.L. 2005. Selective probiotic bacteria induce IL-10-producing regulatory T cells in vitro by modulating dendritic cell function through dendritic cell-specific intercellular adhesion molecule 3-grabbing nonintegrin. J. Allergy Clin. Immunol. 115(6): 1260-1267. PMID: 15940144. doi: 10.1016/j.jaci.2005. 03.036 .

Sonnenburg, E.D., Smits, S.A., Tikhonov, M., Higginbottom, S.K., Wingreen, N.S., and Sonnenburg, J.L. 2016. Diet-induced extinctions in the gut microbiota compound over generations. Nature. 529(7585):212-215. PMID: 26762459. doi: 10.1038/ nature16504.

Sonnenburg, J.L., and Backhed, F. 2016. Diet-microbiota interactions as moderators of human metabolism. Nature. 535(7610):56-64. PMID: 27383980. doi: $10.1038 /$ nature 18846 .

Tan, J., McKenzie, C., Vuillermin, P.J., Goverse, G., Vinuesa, C.G., Mebius, R.E., Macia, L., and Mackay, C.R. 2016. Dietary fiber and bacterial SCFA enhance oral tolerance and protect against food allergy through diverse cellular pathways. Cell Rep. 15(12):2809-2824. PMID: 27332875. doi: 10.1016/j. celrep.2016.05.047.

Tao, Y., Nomura, M., Kitabatake, N., and Tani, F. 2007. Mouse CD40-transfected cell lines cannot exhibit the binding and RANTES-stimulating activity of exogenous heat shock protein 70 . Mol. Immunol. 44(6):1262-1273. PMID: 16930707. doi: 10.1016/j. molimm.2006.06.002.

Thaiss, C.A., Zmora, N., Levy, M., and Elinav, E. 2016. The microbiome and innate immunity. Nature. 535(7610):65-74. PMID: 27383981. doi: 10.1038/ nature 18847.

Thomas, C.M., Hong, T., van Pijkeren, J.P., Hemarajata, P., Trinh, D.V., Hu, W., Britton, R.A., Kalkum, M., and Versalovic, J. 2012. Histamine derived from probiotic Lactobacillus reuteri suppresses TNF via modulation of PKA and ERK signaling. PLoS ONE. 7(2):e31951. PMID: 22384111. doi: 10.1371/journal.pone.0031951.

Thorburn, A.N., McKenzie, C.I., Shen, S., Stanley, D., Macia, L., Mason, L.J., Roberts, L.K., Wong, C.H., Shim, R., Robert, R., Chevalier, N., Tan, J.K., Marino, E., Moore, R.J., Wong, L., McConville, M.J., Tull, D.L., Wood, L.G., Murphy, V.E., Mattes, J.,
Gibson, P.G., and Mackay, C.R. 2015. Evidence that asthma is a developmental origin disease influenced by maternal diet and bacterial metabolites. Nat. Commun. 6:7320. PMID: 26102221. doi: 10.1038/ ncomms8320.

Tien, M.T., Girardin, S.E., Regnault, B., Le Bourhis, L., Dillies, M.A., Coppee, J.Y., Bourdet-Sicard, R., Sansonetti, P.J., and Pedron, T. 2006. Antiinflammatory effect of Lactobacillus casei on Shigellainfected human intestinal epithelial cells. J. Immunol. 176(2):1228-1237. PMID: 16394013. doi: 10.4049/ jimmunol.176.2.1228.

Tomosada, Y., Villena, J., Murata, K., Chiba, E., Shimazu, T., Aso, H., Iwabuchi, N., Xiao, J.Z., Saito, T., and Kitazawa, H. 2013. Immunoregulatory effect of bifidobacteria strains in porcine intestinal epithelial cells through modulation of ubiquitin-editing enzyme A20 expression. PLoS ONE. 8(3):e59259. PMID: 23555642. doi: 10.1371/journal.pone. 0059259.

Trompette, A., Gollwitzer, E.S., Yadava, K., Sichelstiel, A.K., Sprenger, N., Ngom-Bru, C., Blanchard, C., Junt, T., Nicod, L.P., Harris, N.L., and Marsland, B.J. 2014. Gut microbiota metabolism of dietary fiber influences allergic airway disease and hematopoiesis. Nat. Med. 20(2):159-166. PMID: 24390308. doi: 10.1038/nm.3444.

Tulini, F.L., Hymery, N., Choiset, Y., Chobert, J.-M., Haertlé, T., De Martinis, E.C.P., and Le Blay, G. 2015. Milk fermented with the probiotic candidate Lactobacillus paracasei FT700 induces differentiation of monocytes toward macrophages in vitro. J. Funct. Foods. 15:533-540. doi: 10.1016/j.jff.2015.04.004.

Underwood, M.A., Gaerlan, S., De Leoz, M.L., Dimapasoc, L., Kalanetra, K.M., Lemay, D.G., German, J.B., Mills, D.A., and Lebrilla, C.B. 2015. Human milk oligosaccharides in premature infants: Absorption, excretion, and influence on the intestinal microbiota. Pediatr. Res. 78(6):670-677. PMID: 26322410. doi: 10.1038/pr.2015.162.

Valladares, R., Bojilova, L., Potts, A.H., Cameron, E., Gardner, C., Lorca, G., and Gonzalez, C.F. 2013. Lactobacillus johnsonii inhibits indoleamine 2,3-dioxygenase and alters tryptophan metabolite levels in BioBreeding rats. FASEB J. 27(4):1711-1720. PMID: 23303207. doi: 10.1096/fj.12-223339.

van Baarlen, P., Wells, J.M., and Kleerebezem, M. 2013. Regulation of intestinal homeostasis and immunity with probiotic lactobacilli. Trends Immunol. 34(5):208-215. PMID: 23485516. doi: 10.1016/j.it.2013.01.005. 
Vatanen, T., Kostic, A.D., d'Hennezel, E., Siljander, H., Franzosa, E.A., Yassour, M., Kolde, R., Vlamakis, H., Arthur, T.D., Hamalainen, A.M., Peet, A., Tillmann, V., Uibo, R., Mokurov, S., Dorshakova, N., Ilonen, J., Virtanen, S.M., Szabo, S.J., Porter, J.A., Lahdesmaki, H., Huttenhower, C., Gevers, D., Cullen, T.W., Knip, M., Group, D.S., and Xavier, R.J. 2016. Variation in microbiome LPS immunogenicity contributes to autoimmunity in humans. Cell. 165(6):1551. PMID: 27259157. doi: 10.1016/j.cell. 2016.05.056.

Villena, J., Suzuki, R., Fujie, H., Chiba, E., Takahashi, T., Tomosada, Y., Shimazu, T., Aso, H., Ohwada, S., Suda, Y., Ikegami, S., Itoh, H., Alvarez, S., Saito, T., and Kitazawa, H. 2012. Immunobiotic Lactobacillus jensenii modulates the Toll-like receptor 4 -induced inflammatory response via negative regulation in porcine antigen-presenting cells. Clin. Vaccine Immunol. 19(7):1038-1053. PMID: 22573738. doi: 10.1128/ CVI.00199-12.

Vogel, C.F., Khan, E.M., Leung, P.S., Gershwin, M.E., Chang, W.L., Wu, D., Haarmann-Stemmann, T., Hoffmann, A., and Denison, M.S. 2014. Cross-talk between aryl hydrocarbon receptor and the inflammatory response: A role for nuclear factor- $\kappa \mathrm{B}$. J. Biol. Chem. 289(3):1866-1875. PMID: 24302727. doi: 10.1074/jbc.M113.505578.

Vogt, L., Meyer, D., Pullens, G., Faas, M., Smelt, M., Venema, K., Ramasamy, U., Schols, H.A., and De Vos, P. 2015a. Immunological properties of inulintype fructans. Crit. Rev. Food Sci. Nutr. 55(3): 414-436. PMID: 24915372. doi: 10.1080/10408398. 2012.656772.

Vogt, L.M., Meyer, D., Pullens, G., Faas, M.M., Venema, K., Ramasamy, U., Schols, H.A., and de Vos, P. 2014. Toll-like receptor 2 activation by $\beta 2 \rightarrow 1$-fructans protects barrier function of T84 human intestinal epithelial cells in a chain length-dependent manner. J. Nutr. 144(7):1002-1008. PMID: 24790027. doi: 10.3945/jn.114.191643.

Vogt, S.L., Pena-Diaz, J., and Finlay, B.B. $2015 b$. Chemical communication in the gut: Effects of microbiota-generated metabolites on gastrointestinal bacterial pathogens. Anaerobe. 34:106-115. PMID: 25958185. doi: 10.1016/j.anaerobe.2015.05.002.

Voltan, S., Martines, D., Elli, M., Brun, P., Longo, S., Porzionato, A., Macchi, V., D’Inca, R., Scarpa, M., Palu, G., Sturniolo, G.C., Morelli, L., and Castagliuolo, I. 2008. Lactobacillus crispatus $\mathrm{M} 247$-derived $\mathrm{H}_{2} \mathrm{O}_{2}$ acts as a signal transducing molecule activating peroxisome proliferator activated receptor-gamma in the intestinal mucosa. Gastroenterology. 135(4): 1216-1227. PMID: 18722375. doi: 10.1053/j.gastro. 2008.07.007.

von Schillde, M.A., Hormannsperger, G., Weiher, M., Alpert, C.A., Hahne, H., Bauerl, C., van Huynegem, K., Steidler, L., Hrncir, T., Perez-Martinez, G., Kuster, B., and Haller, D. 2012. Lactocepin secreted by Lactobacillus exerts anti-inflammatory effects by selectively degrading proinflammatory chemokines. Cell Host Microbe. 11(4):387-396. PMID: 22520466. doi: 10.1016/j.chom.2012.02.006.

Vong, L., Pinnell, L.J., Maattanen, P., Yeung, C.W., Lurz, E., and Sherman, P.M. 2015. Selective enrichment of commensal gut bacteria protects against Citrobacter rodentium-induced colitis. Am. J. Physiol. Gastrointest. Liver Physiol. 309(3): G181-G192. PMID: 26067845. doi: 10.1152/ajpgi. 00053.2015.

Wagar, L.E., Champagne, C.P., Buckley, N.D., Raymond, Y., and Green-Johnson, J.M. 2009. Immunomodulatory properties of fermented soy and dairy milks prepared with lactic acid bacteria. J. Food Sci. 74(8):M423-M430. PMID: 19799669. doi: 10.1111/j.1750-3841.2009.01308.x.

Wang, L., Cao, H., Liu, L., Wang, B., Walker, W.A., Acra, S.A., and Yan, F. 2014. Activation of epidermal growth factor receptor mediates mucin production stimulated by $\mathrm{p} 40$, a Lactobacillus rhamnosus GG-derived protein. J. Biol. Chem. 289(29): 20234-20244. PMID: 24895124. doi: 10.1074/jbc. M114.553800.

Wang, Y., Liu, L., Moore, D.J., Shen, X., Peek, R.M., Acra, S.A., Li, H., Ren, X., Polk, D.B., and Yan, F. 2016. An LGG-derived protein promotes IgA production through upregulation of APRIL expression in intestinal epithelial cells. Mucosal Immunol. PMID: 27353252. doi: 10.1038/mi.2016.57.

Wentworth, C.C., Alam, A., Jones, R.M., Nusrat, A., and Neish, A.S. 2011. Enteric commensal bacteria induce extracellular signal-regulated kinase pathway signaling via formyl peptide receptor-dependent redox modulation of dual specific phosphatase 3. J. Biol. Chem. 286(44):38448-38455. PMID: 21921027. doi: 10.1074/jbc.M111.268938.

Wheeler, M.L., Limon, J.J., Bar, A.S., Leal, C.A., Gargus, M., Tang, J., Brown, J., Funari, V.A., Wang, H.L., Crother, T.R., Arditi, M., Underhill, D.M., and Iliev, I.D. 2016. Immunological consequences of intestinal fungal dysbiosis. Cell Host Microbe. 19(6):865-873. PMID: 27237365. doi: 10.1016/j.chom. 2016.05.003. 
Wikoff, W.R., Anfora, A.T., Liu, J., Schultz, P.G., Lesley, S.A., Peters, E.C., and Siuzdak, G. 2009. Metabolomics analysis reveals large effects of gut microflora on mammalian blood metabolites. Proc. Natl. Acad. Sci. USA. 106(10):3698-3703. PMID: 19234110. doi: 10.1073/pnas.0812874106.

Wu, G.D., Compher, C., Chen, E.Z., Smith, S.A., Shah, R.D., Bittinger, K., Chehoud, C., Albenberg, L.G., Nessel, L., Gilroy, E., Star, J., Weljie, A.M., Flint, H.J., Metz, D.C., Bennett, M.J., Li, H., Bushman, F.D., and Lewis, J.D. 2016. Comparative metabolomics in vegans and omnivores reveal constraints on diet-dependent gut microbiota metabolite production. Gut. 65(1): 63-72. PMID: 25431456. doi: 10.1136/gutjnl-2014308209.

Yan, F., Cao, H., Cover, T.L., Whitehead, R., Washington, M.K., and Polk, D.B. 2007. Soluble proteins produced by probiotic bacteria regulate intestinal epithelial cell survival and growth. Gastroenterology. 132(2):562-575. PMID: 17258729. doi: 10.1053/j.gastro.2006.11.022.

Yan, F., Liu, L., Dempsey, P.J., Tsai, Y.H., Raines, E.W., Wilson, C.L., Cao, H., Cao, Z., Liu, L., and Polk, D.B. 2013. A Lactobacillus rhamnosus GG-derived soluble protein, $\mathrm{p} 40$, stimulates ligand release from intestinal epithelial cells to transactivate epidermal growth factor receptor. J. Biol. Chem. 288(42):30742-30751. PMID: 24043629. doi: 10.1074/jbc.M113.492397.

Zelante, T., Iannitti, R.G., Cunha, C., De Luca, A., Giovannini, G., Pieraccini, G., Zecchi, R., D’Angelo, C., Massi-Benedetti, C., Fallarino, F., Carvalho, A.,
Puccetti, P., and Romani, L. 2013. Tryptophan catabolites from microbiota engage aryl hydrocarbon receptor and balance mucosal reactivity via interleukin-22. Immunity. 39(2):372-385. PMID: 23973224. doi: 10.1016/j.immuni.2013.08.003.

Zenhom, M., Hyder, A., de Vrese, M., Heller, K.J., Roeder, T., and Schrezenmeir, J. 2011. Prebiotic oligosaccharides reduce proinflammatory cytokines in intestinal Caco-2 cells via activation of PPAR $\gamma$ and peptidoglycan recognition protein 3. J. Nutr. 141(5):971-977. PMID: 21451128. doi: 10.3945/ jn.110.136176.

Zhang, C., Derrien, M., Levenez, F., Brazeilles, R., Ballal, S.A., Kim, J., Degivry, M.C., Quere, G., Garault, P., van Hylckama Vlieg, J.E., Garrett, W.S., Dore, J., and Veiga, P. 2016. Ecological robustness of the gut microbiota in response to ingestion of transient food-borne microbes. ISME J. 10(9): 2235-2245. PMID: 26953599. doi: 10.1038/ismej. 2016.13.

Zhou, W., Yuan, Y., Li, J., Yuan, W.M., Huang, L.G., and Zheng, S.W. 2015. Effect of Bifidobacterium on the mRNA expression levels of TRAF6, GSK-3beta, and microRNA-146a in LPS-stimulated rat intestinal epithelial cells. Genet. Mol. Res. 14(3):10050-10056. PMID: 26345941. doi: 10.4238/2015.August.21.11.

Zou, W., Wolchok, J.D., and Chen, L. 2016. PD-L1 (B7-H1) and PD-1 pathway blockade for cancer therapy: Mechanisms, response biomarkers, and combinations. Sci. Transl. Med. 8(328):328rv4. PMID: 26936508. doi: 10.1126/scitranslmed.aad7118. 